\title{
Women legislators and economic performance
}

Thushyanthan Baskaran, ${ }^{1}$ Sonia Bhalotra, ${ }^{2}$ Brian Min, ${ }^{3}$ and Yogesh Uppal

May 2018 
Abstract: There has been a phenomenal global increase in the proportion of women in politics in the last 20 years. While there is evidence that raising the share of women politicians has substantive impacts on the composition of government spending, there is scarcely any evidence of how it influences economic performance. We investigate this using comprehensive data on competitive elections to India's state legislative assemblies, exploiting close elections between men and women to isolate the causal effect of legislator gender in a regression discontinuity design. We identify significantly higher growth in economic activity in constituencies that elect women. Probing mechanisms, we find evidence that women legislators are less likely to be criminal and corrupt, more efficacious, and less vulnerable to political opportunism. We find no evidence of negative spillovers to neighbouring (male-led) constituencies, consistent with net growth.

Keywords: women legislators, political representation, corruption, economic growth JEL classification: D72, D78, H44, H73

Acknowledgements: All errors are our own. We acknowledge support from the International Growth Center for the project 'Female politicians and economic growth' (IGC G2015-73). Bhalotra acknowledges partial support from ESRC Grant ES/L009153/1 awarded to the Research Centre for Micro-Social Change at ISER, University of Essex. We are grateful to Ray Fisman and Dan Keniston for sharing their data with us, and to Sam Asher, Irma Clots-Figueras, Lakshmi Iyer, and Paul Novosad for useful discussions. The paper has benefited from presentation at the Navarra Centre for International Development workshop in Madrid 2016, the EEA 2017 meeting in Lisbon, the IIPF 2017 meeting in Tokyo, the NEUDC meetings, the Gender-Governance (GGL) Conference 2017 in Göttingen, IFS London, University of Michigan, the University of Marburg, University of Reading, and the University of Essex. This paper was commissioned by UNU-WIDER as a key note for the 17th Nordic Conference on Development Economics.

\footnotetext{
${ }^{1}$ School of Economic Disciplines, University of Siegen, Siegen, Germany; ${ }^{2}$ ISER and Department of Economics, University of Essex, Colchester, UK, corresponding author: Sonia R srbhal@essex.ac.uk; ${ }^{3}$ Department of Political Science, University of Michigan, Ann Arbor, USA; ${ }^{2}$ Department of Economics, Youngstown State University, Youngstown, USA.
}

This research study is released in connection with the 17th Nordic Conference on Development Economics, jointly organized with Aalto University School of Business, University of Tampere, and the Nordic Network in Development Economics, on 11-12 June 2018 in Helsinki, Finland.

Copyright (C) UNU-WIDER 2018

Information and requests: publications@wider.unu.edu

ISSN 1798-7237 ISBN 978-92-9256-489-6 https://doi.org/10.35188/UNU-WIDER/2018/489-6

Typescript prepared by Gary Smith.

The United Nations University World Institute for Development Economics Research provides economic analysis and policy advice with the aim of promoting sustainable and equitable development. The Institute began operations in 1985 in Helsinki, Finland, as the first research and training centre of the United Nations University. Today it is a unique blend of think tank, research institute, and UN agency — providing a range of services from policy advice to governments as well as freely available original research.

The Institute is funded through income from an endowment fund with additional contributions to its work programme from Finland, Sweden, and the United Kingdom as well as earmarked contributions for specific projects from a variety of donors.

Katajanokanlaituri 6 B, 00160 Helsinki, Finland

The views expressed in this paper are those of the author(s), and do not necessarily reflect the views of the Institute or the United Nations University, nor the programme/project donors. 
More than 100 countries have introduced quotas for women in parliament or in party lists in the last two decades (Besley et al. 2013; Dahlerup 2006), and the percentage of women in parliament worldwide has more than doubled in the last 20 years, standing at 22.8 per cent in June 2016. ${ }^{1}$ The feminization of politics is one of the most exciting political phenomena of our time. Yet, we do not know what it portends for growth, the rising tide that is thought to lift all boats. In this paper we present the first systematic examination of whether women politicians are good for economic growth.

The association of women with redistributive politics and a tolerance of higher taxes (Campbell 2004; Edlund and Pande 2002; Edlund et al. 2005) makes it plausible that, at least in the short to medium term, women politicians are less effective than men at promoting growth. Women have been shown to favour public goods investments, such as in education and health (Bhalotra and Clots-Figueras 2014; ClotsFigueras 2012), which have only very long-term returns. However, women legislators might promote growth if they are less corrupt (Beaman et al. 2006; Brollo and Troiano 2014), with visible impacts even in the short term (Dollar et al. 2001; Swamy et al. 2001; Mauro 1995; Prakash et al. 2014). Or, if women who select into public office have a stronger sense of public mission and are more motivated to perform (perhaps to meet higher expectations), they may be more effective at managing economic growth. ${ }^{2}$

We know of no causal estimates linking economic performance to the gender of politicians, but a few recent studies examine the impact of women on corporate boards on firm performance. The results of these studies are ambiguous, suggesting negative impacts or no impact (Ahern and Dittmar 2012; Gagliarducci and Paserman 2014; Matsa and Miller 2013). However, this evidence base is too small to be conclusive, and the gender composition of decision makers may influence economic performance differently in the political and corporate sectors.

Two factors probably contribute to the scarcity of causal evidence on the relationship between legislator gender and economic performance. First, subregional- and, in particular, constituency-level data on economic activity are not available in most countries. We use satellite imagery of night luminosity as a measure of economic performance, following Henderson et al. (2012) and Chen and Nordhaus (2011). The second constraint on research seeking to produce causal evidence is that constituencies in which women win elections will tend to be systematically different in ways that may be correlated with economic performance. To isolate the role of legislator gender from voter preferences and potentially omitted variables, we use a regression discontinuity design on close elections between men and women. In first-past-the-post elections in which 'the winner takes all', there is a sharp discontinuity at the zero vote margin between the top two candidates. In this setting, the identity (and hence gender) of the winner may be deemed quasi-random (Lee 2008). Comparing constituencies in which a woman won against a man by a narrow margin ('treated') with those in which a man won against a woman by a narrow margin ('control') can then be argued to isolate the causal influence of leader gender.

We examine data for 4,265 state assembly constituencies for the 1992-2012 period which, in most states, spans four elections. This was a period of strong economic growth. It is also a period in which the share of state legislative assembly seats won by women increased, from about 4.5 per cent to close to 8 per cent. Important for our purposes, there was vast regional variation in both the gender composition of state legislators and luminosity growth (see Figures 1 and 2).

\footnotetext{
${ }^{1}$ In contrast, only 12 per cent of corporate board members are women.

${ }^{2}$ See, for instance, www.forbes.com/sites/kerryhannon/2010/11/19/top-five-reasons-why-women-flock-to-nonprofit-jobs.
} 
Figure 1: Female Legislators: 1992-2008

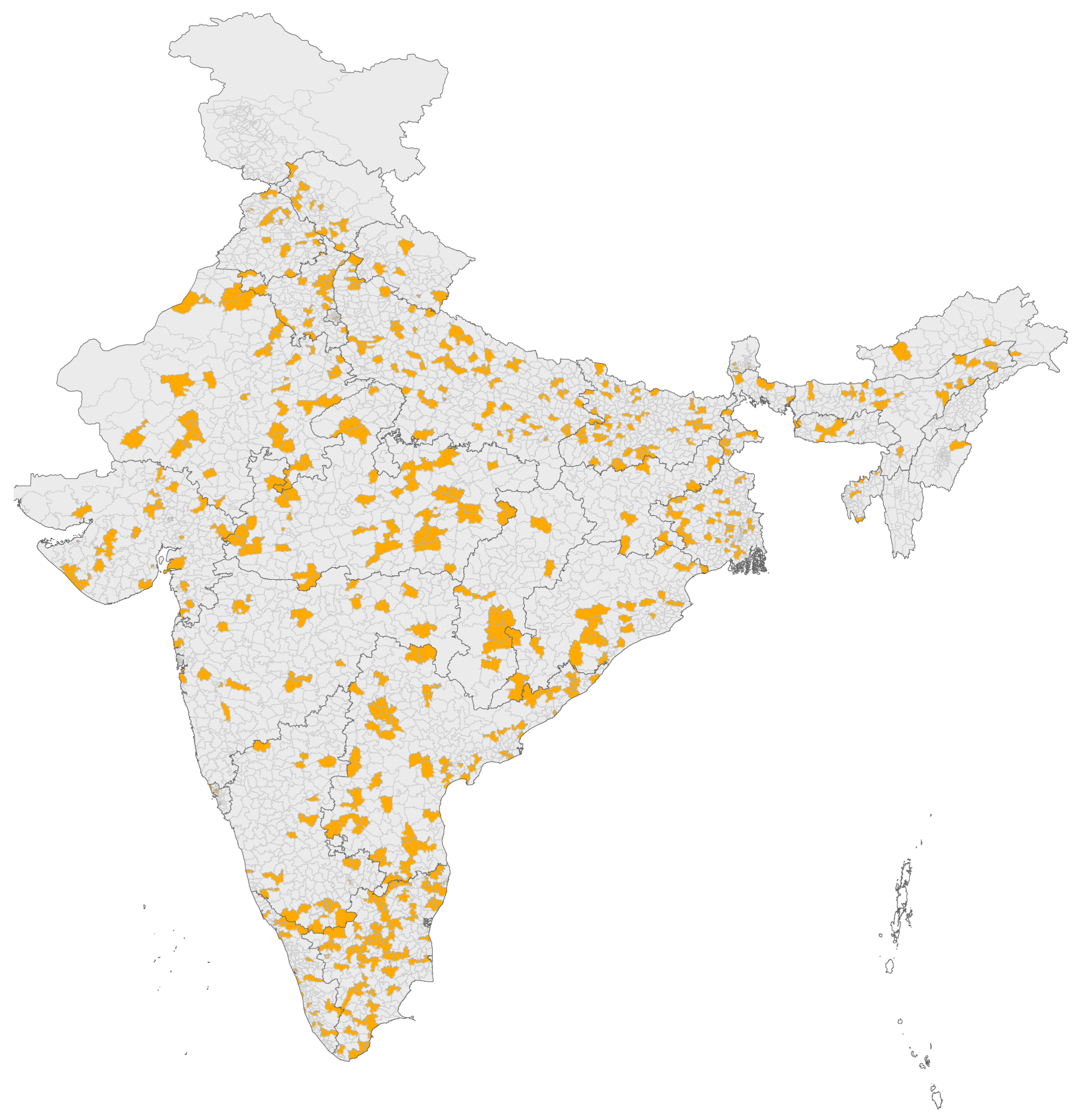

Note: Highlighted constituencies indicate those in which a female candidate won an assembly constituency seat in state elections between 1992 and 2008.

Source: authors, based on the Election Commission of India. 
Figure 2: Level of luminosity in India

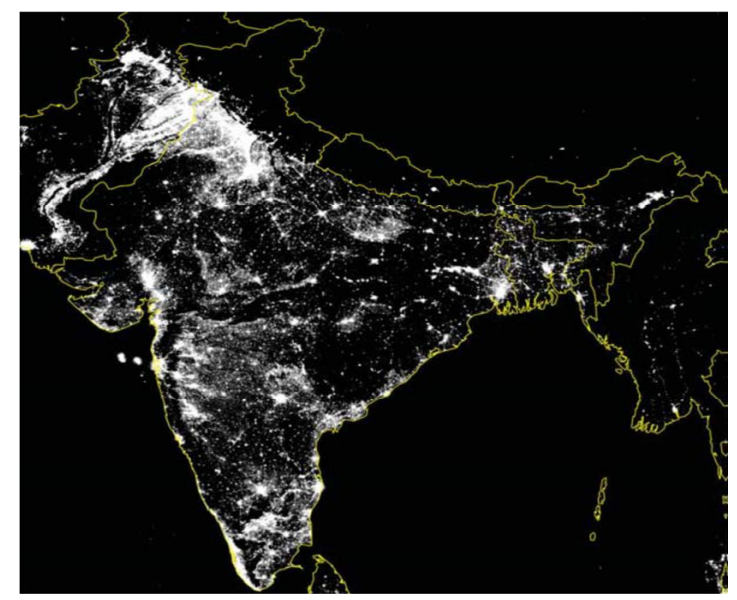

(a) Luminosity in 1992

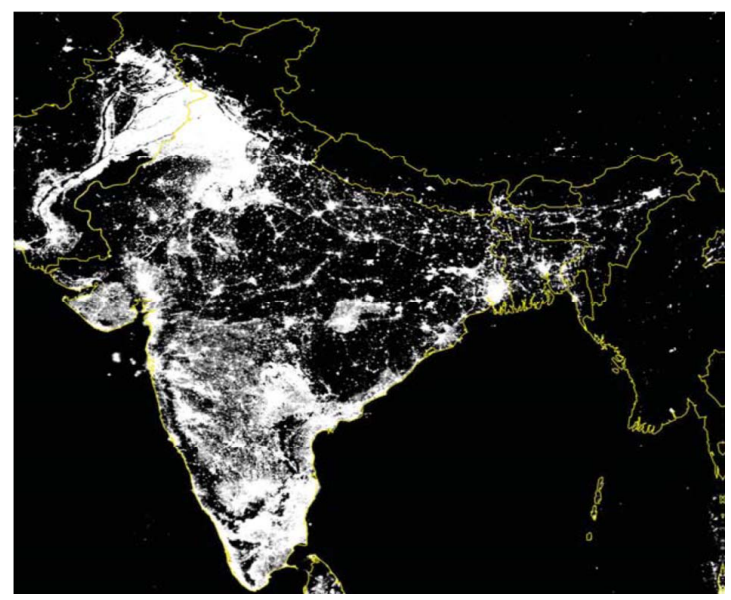

(b) Luminosity in 2009

Note: (a) and (b) show the level of average luminosity in India in 1992 and 2009, respectively. The average growth rate of GDP in India during this period was about 120 per cent.

Source for all figures: DMSP-OLS v4 Time Stable Annual Composites from NOAA National Geophysical Data Center.

We find that women legislators in India raise economic performance in their constituencies by about 1.8 percentage points per year more than male legislators. ${ }^{3}$ Estimates on our sample that do not account for selection show no significant relationship between legislator gender and luminosity growth at the constituency level. Similarly, a scatter plot of GDP against the share of women in national parliaments (see Figure A.3) indicates no relationship between the two variables. This underlines the importance of accounting for selection.

To assess impacts of raising the share of women legislators on overall economic growth, we tested for the possibility of negative spillovers that may arise-for instance, if constituencies compete for shares of the state budget. Using neighbours of every woman-led constituency, we can reject negative spillovers. This is consistent with yardstick competition between neighbours (Besley and Case 1995) and with improvements in publicly provided infrastructure like roads having some positive effect on neighbours as infrastructure does not stop abruptly at constituency boundaries.

In probing mechanisms, we explore differences between male and female legislators in corruption (characteristics and behaviour), efficiency (completion of federally funded road infrastructure projects), and motivation (behaviour as a function of whether the legislator is elected in a swing constituency), each of which has been associated with economic growth in developing countries.

We identify a role for criminality and corruption in explaining better performance under women leaders. Male legislators (in the close election sample) are about three times as likely as female legislators to have criminal charges pending against them, and we estimate that this can explain about one-quarter of the difference in growth between male- and female-led constituencies. We buttress this result with regression discontinuity (RD) estimates of actual corruption in office. Using a measure discussed and validated by Fisman et al. (2014), we find that the rate at which women accumulate assets while in office is 10 percentage points lower per annum than it is for men. These findings align with experimental evidence that women are more fair, more risk-averse, and less likely to engage in criminal and other

\footnotetext{
${ }^{3}$ Our estimates indicate that luminosity growth is about 15 percentage points higher in female-led than in male-led constituencies. We estimate the GDP-luminosity elasticity from Indian state level data as 0.12 and use this to translate the marginal effect into GDP growth.
} 
risky behaviour than are men (Andreoni and Vesterlund 2001; Eckel and Grossman 2008; Fletschner et al. 2010). ${ }^{4}$

Since economic infrastructure is an important input to economic growth, especially in developing countries (Jacoby 2000), we also analyse legislator performance in implementation of a massive federally funded village road construction programme. We find that, although male and female politicians are equally likely to negotiate federal projects for road building in their constituencies, women are more likely to oversee completion of these projects. We interpret this as a marker of efficacy. Since road construction has higher returns for men (Asher and Novosad 2018), this finding also establishes that women politicians are not exclusively focused upon serving the interests of women voters, a commonly held claim. ${ }^{5}$

Finally, separating the sample into swing and other constituencies, we find that the relative economic performance of women legislators is higher only in non-swing constituencies. This is consistent with greater political opportunism among men or with women legislators having greater intrinsic motivation.

Overall, our analysis of mechanisms suggests that differences in preferences between men and women play a role in determining the better economic performance of women legislators. We provide important new evidence at a time when women are increasingly participating in government across the globe. In India, a historic constitutional amendment proposing to reserve one-third of all federal and state assembly seats for women was passed by the upper house of the federal parliament in 2010. However, this bill still needs to pass the national parliament and state assemblies. Our findings are of interest beyond India, given the scarcity of evidence on the question of how legislator gender is associated with economic performance. We contribute new evidence to a literature on political identity and substantive representation (Besley and Coate 1997; Osborne and Slivinski 1996) that has tended to focus more narrowly upon differences in priorities and preferences of men and women in government.

The remainder of this paper is structured as follows. Section 2 offers contextual information on Indian elections and women's participation. Section 3 presents our empirical strategy. In Section 4, we discuss the electoral and luminosity data. Section 5 presents the main results. In Sections 6 and 7, we discuss alternative interpretations of the results. Section 8 presents a number of extensions. Section 9 concludes.

\section{Context}

India is a large federal country with highly competitive multi-party elections monitored by an independent electoral commission. Electoral fraud is uncommon, although some areas suffer from clientelism and elite capture (Anderson et al. 2014). The current 29 states of the Indian Union are parliamentary democracies in which, typically, a new legislative assembly is elected every five years. There is a high degree of turnover at the state level, with state governments often voted out of office. Assembly constituencies are also characterized by significant turnover. In fact, in contrast to the case of the United

\footnotetext{
4 These studies do not investigate whether women influence economic growth.

${ }^{5}$ For instance, see Bhalotra and Clots-Figueras (2014); Brollo and Troiano (2014); Chaney et al. (1998); Chattopadhyay and Duflo (2004); Clots-Figueras (2012); Edlund et al. (2005); Iyer et al. (2012); Miller (2007); Svaleryd (2009); Thomas (1991). Among the findings of these studies are that women in politics have influenced the passage of abortion laws in the United States, equal inheritance rights legislation, the reporting of crime against women, and the promotion of public health inputs to child survival in India; and government spending on child care, education, and elderly care in Sweden. A few studies find no significant influence of the gender of local politicians on policy choices (Ferreira and Gyourko 2014; Rigon and Tanzi 2012)
} 
States, but similar to the case of Brazil, incumbents in India are less likely to win than challengers (Uppal 2009). Members of legislative assemblies (legislators) are chosen according to a first-past-the-post system in single-member constituencies. Voters vote for individual candidates rather than party lists. Successful candidates are typically appointed and supported by an established party. In fact, parties are crucial arbiters of political careers, given the high costs of running for office in India. In the 2009 federal elections, the average cost of winning a seat was around US\$2 million (Tiwari 2014), a sum that most candidates would struggle to raise without the support of sophisticated party organizations. While there are political quotas for certain minority tribes and castes at the local, state, and national levels, gender quotas in India are only at the local level and only since 1993 (Chattopadhyay and Duflo 2004).

State legislators shape policy. They influence the flow of federal funds and the financing of village councils and they are responsible, inter alia, for roads, electricity, law and order, health, and education. Political manipulation by state governments can influence the allocation of federal transfers (Khemani 2006) and of federally funded development programmes (Gupta and Mukhopadhyay 2014). Legislators can influence economic conditions in their constituencies by, for instance, improving the supply of public services like electricity (Baskaran et al. 2015; Min 2015), attracting 'pork' by lobbying the state government, exerting efforts to pursue development opportunities, and implementing federal or state government programmes more or less effectively.

Evidence emerging from political quotas in village and town councils and analysis of close elections to state assemblies suggest that women politicians have different priorities from men, tending to favour the concerns of women and children (see references in Section 1). Despite an increase in the share of women legislators, women remain vastly under-represented in Indian federal and state politics, their share oscillating around 10 per cent in recent years (Beaman et al. 2012). This reflects not so much lower chances of winning conditional on standing, but that fewer women come forward as candidates (Bhalotra et al. 2017). This may be because women dislike competitive or corrupt environments or because party leaders discriminate against women in the nomination process (Spary 2014). Figure 1 shows that constituencies in which women win are fairly evenly distributed across the country, so our analysis does not pertain to a specific region.

\section{$3 \quad$ Empirical strategy}

We aim to estimate the causal effect of election of a woman legislator on economic activity in her constituency. As discussed in more detail in the following section, there are no constituency-level economic data such as GDP, so we proxy economic activity with night-time luminosity. If the election of women was randomly determined, constituencies that elected a man would serve as a valid counterfactual for constituencies that elected a woman. However, the election of women is unlikely to be random. For instance, one might expect that constituencies with more progressive voters are more likely to elect women, other things being equal. This creates the identification challenge that unobserved differences between constituencies that elect women rather than men are correlated with the outcome (economic activity).

To address this challenge, we exploit the discontinuity in electoral outcomes that arises in first-past-thepost electoral systems by comparing female and male winners in close elections, defined as elections in which the margin of victory between the winner and the runner-up is arbitrarily small. Previous work shows that, in these circumstances, the identity of the winner is quasi-random (Lee 2008).

The estimated model is: 


$$
y_{i s t}=\alpha+\tau * \text { woman }_{i s t}+f\left(\operatorname{margin}_{i s t}\right)+\varepsilon_{i s t},
$$

where $y_{i s t}$ is average growth of light in constituency $i$ in state $s$ over the election term $t$, and margin $_{i s t}$ is the forcing variable. Since we restrict the sample to elections in which the top two vote-getters are a man and a woman, margin $_{i s t}$ is the margin of victory, defined as the difference between the vote shares of the female and the male candidates. So, by construction, it is positive when a woman wins against a male runner-up and negative when a male wins against a female runner-up. At a (notional) margin of zero, the gender of the constituency leader changes discontinuously from male to female. We can think of the treatment woman $i s t$ as an indicator for the winner being a woman, defined as follows:

$$
\begin{aligned}
\text { woman }_{i s t} & =1 \text { if } \operatorname{margin}_{i s t}>0 \\
& =0 \text { if } \text { margin }_{i s t} \leq 0 .
\end{aligned}
$$

The RD design considers a close neighbourhood, $\lambda$, around the threshold margin of zero and premises that as $\lambda$ goes to zero the differences between constituencies that elected a female candidate and those that elected a male candidate vanish, allowing us to identify the causal effect of electing a woman legislator:

$$
\lim _{\lambda \rightarrow 0^{+}} E\left[y_{i s t} \mid 0<\operatorname{margin}_{i s t} \leq \lambda\right]-\lim _{\lambda \rightarrow 0^{-}} E\left[y_{i s t} \mid-\lambda \leq \operatorname{margin}_{i s t}<0\right]=\tau .
$$

This is the difference in the average outcomes of constituencies that barely elected a female legislator against a male runner-up and constituencies that barely elected a male legislator against a female runnerup. Since there is no within-election-term variation in the treatment variable (female legislator), we average the growth of light over an election term. Standard errors are clustered at the constituency level to allow for within-constituency correlation of the errors over time. The regression discontinuity design (RDD) assumption that the distribution of the error term, $\varepsilon_{i s t}$, is continuous in the forcing variable is weaker than the identifying assumptions that other selection-on-observables methods rely upon.

We estimate the discontinuity using local linear regressions as suggested by Gelman and Imbens (2014). We also report results for several bandwidth choices, including the optimal bandwidth procedure suggested by Imbens and Kalyanaraman (2012). In a further robustness check, we investigate sensitivity of our results to an alternative definition of the victory margin, using the larger sample of all races in which a female contested, irrespective of whether or not she was ranked among the top two in vote share (Meyerson 2014). As discussed in Section 1, we shall study a number of potential mechanisms, investigate heterogeneity in impact, and conduct several robustness checks. The empirical specifications for these extensions of the main analysis are presented together with the findings below.

4

Data

Table A.2 summarizes the main outcome variables (Panel A) and the predetermined covariates (Panel B) in our data. It also provides summary statistics for variables available from the candidates' self-reported affidavits (Panel C). In this section, we discuss the luminosity data used to define the dependent variable, the electoral data, and the road construction data. 


\subsection{Night lights data}

We use satellite imagery of the earth at night that is gathered by several satellites orbiting the earth under the U.S. Air Force Defense Meteorological Satellite Program's Operational Linescan System (DMSPOLS). ${ }^{6}$ The data are processed by the National Oceanic and Atmospheric Agency's (NOAA) National Geophysical Data Center (NGDC) to exclude late-evening sunlight due to longer days in the summer months, the effects of lunar illuminance, observations with clouds, effects of auroral lights, and active fires. The images are scaled onto a geo-referenced 30 arc-second grid (approximately $1 \mathrm{~km}^{2}$ ). Each pixel is encoded with a measure of its annual average brightness on a six-bit scale from 0 to 63 . Night lights data were first digitized in 1992 and our electoral data run through 2012.

Henderson et al. (2012) provide a detailed discussion of the satellite data, the filtering done to it, and the caveats to interpreting light growth as economic activity. Importantly, they present various evidence that although GDP is widely gathered and hence used, it is often very unreliable in developing countries where the informal sector is large, making it harder to verify inputs, outputs, incomes, and profits; also see Bhalotra and Umana-Aponte (2015) and Jerven (2013). GDP and night lights are two errorprone measures of economic activity, and it is unclear which is measured with more error, but the great advantage of night lights data, exploited here, is that they are available at the very local level annually and can be mapped into units of interest such as, in this case, Indian state assembly constituencies.

We overlay a map of 4,265 Indian state assembly constituencies to create constituency-level light output data as the sum of total light emitted by each pixel within constituency boundaries divided by the area of the constituency (light density). We calculated the growth of light as the difference in the logarithm of light density in years $t+1$ and $t .^{7}$ Since we are interested in the performance of a legislator over an entire election term (usually five years), we create our main outcome variable as average annual growth over an election term and then annualize it.

To validate our contention that night light growth measures economic growth in India, we use statelevel GDP data, which is the smallest administrative unit for which consistent time series data on GDP are available through the study period. Figure 3 plots a scatter of the data which suggests a strong correlation. Panel data estimate that condition on state and year fixed effects indicate that a 1 per cent increase in night lights is associated with a 0.12 per cent increase in GDP (see Table A.3). Using Indian district level GDP data that are available for a few recent years, Bickenbach et al. (2013) estimate an elasticity of 0.107. Using global data, Henderson et al. (2012) estimate an elasticity of about 0.3.

\subsection{Election data}

The election data are drawn from successive editions of the Statistical Reports on General Elections to Legislative Assembly of States, published by the Election Commission of India. For each election, the reports contain candidate names, vote counts, gender, and party affiliation; assembly constituency names and codes; year of the election, size of the electorate, total number of votes cast, and number of valid votes. India currently has 29 states. Our data, which cover about 99 per cent of the population in India, include all states and the union territory of Delhi, and exclude the northern state of Jammu and Kashmir and other smaller union territories. ${ }^{8}$ A constitutional amendment in 1976 fixed the boundaries of con-

\footnotetext{
6 The data sources, availability, and summary statistics on all variables can be found in Tables A.1 and A.2, respectively.

${ }^{7}$ As some of the light values are zero, we add 1 to each value before taking logs.

${ }^{8}$ In 2000, three states—Bihar, Madhya Pradesh, and Uttar Pradesh—were partitioned to make three additional states. The newly formed states are Chhattisgarh (from Madhya Pradesh), Jharkhand (from Bihar), and Uttarakhand (from Uttar Pradesh).
} 


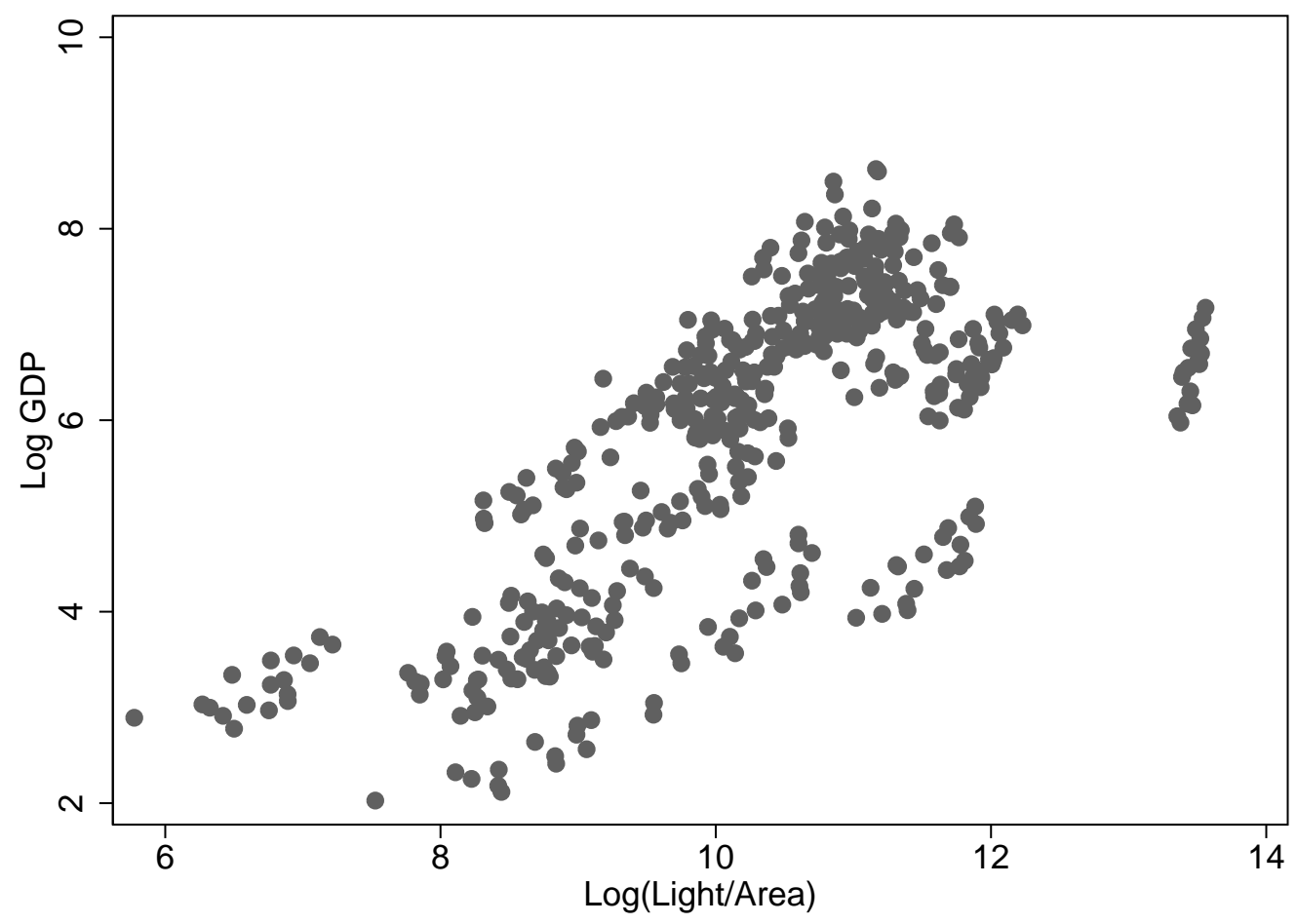

Note: Log(light/area) is the natural log of total light output of a state in a given year divided by its geographical area. Log(GDP) is the natural log of real GDP for each state. The time period is 1992-2009.

Source: authors, based on data from NOAA's National Geophysical Data Centre and Directorate of Economics \& Statistics of respective State Governments, India.

stituencies until 2001 to avoid adversely affecting representation of states that implemented population control measures. The fourth Delimitation Commission empowered by the Delimitation Act of 2002 set out to redraw constituency boundaries based on the 2001 census data. However, the Commission's order was only accepted in 2008 and the first election to use new boundaries was held in 2008 in the state of Karnataka. Due to non-comparability of the pre- and post-delimitation constituencies, we only consider elections held before 2008. However, our data extend until 2012 for states that had not yet held new elections under newly drawn boundaries. ${ }^{9}$

In the analysis period, 1992-2012, there are 16,857 constituency-election years. Of these, 1,709 (10.3 per cent) constituency-election years are in the mixed-gender sample, defined as a sample in which a woman and a man are the top two vote-winners. ${ }^{10}$ Among mixed-gender elections, 471 (27.6 per cent)

Chhattisgarh was allocated 90 constituencies from Madhya Pradesh and Jharkhand was allocated 81 constituencies from Bihar. The constituencies themselves remained unchanged. Uttarakhand was allocated 22 constituencies from Uttar Pradesh, which were redrawn into 70 new constituencies.

9 The data include: Assam till 2010, Bihar till 2009, Goa till 2011, Gujarat till 2011, Himachal Pradesh till 2011, Kerala till 2010, Manipur till 2011, Meghalya till 2012, Mizoram till 2012, Nagaland till 2012, Punjab till 2011, Sikkim till 2011, Tamilnadu till 2010, Tripura till 2012, Uttar Pradesh till 2011, Uttarakhand till 2011, West Bengal till 2010. The remaining states appear in our sample till 2008.

${ }^{10}$ It is notable that when a woman wins, in 91 per cent of cases the runner-up is a man. However, when a man wins, it is only in 6 per cent of cases that the runner-up is a woman. This is because it is only in 30 per cent of constituency-years that at least one woman contests. 
are close elections, defined as elections with a victory margin of less than 5 per cent. In fact one-third of all Indian elections are won with a victory margin of less than 5 per cent, a marker of how competitive Indian elections are in general. ${ }^{11}$

We also utilize data on candidate characteristics drawn from affidavits. The submission of an affidavit became mandatory for all political candidates following a Supreme Court of India order in 2003, the Right to Information Act. The Election Commission of India publishes the affidavits and they contain information on education, assets, liabilities, and criminal accusations. The Association of Democratic Reforms (ADR), an election watchdog, has compiled the information since 2004. ${ }^{12}$ Our analysis using candidate characteristics is thus restricted to state elections held between 2004 and 2008, encompassing one election for each state.

\subsection{Road construction data}

We use completion of federally awarded village road building contracts as a proxy for public goods provision at the constituency level. We have administrative data on a centrally sponsored rural roads construction programme, Pradhan Madri Gram Sadak Yojana (PMGSY), launched in 2000, that aims to provide all-weather road connectivity in rural areas, and forms an integral part of the government of India's poverty-reduction strategy. This program is unprecedented in its scale and scope (Aggarwal 2017).

The National Rural Roads Development Agency (NRRDA), which manages the PMGSY programme, places the administrative records of road projects under PMGSY in the Online Management and Monitoring System (OMMS). We accessed road sanctioning and completion dates. The data are available at the census block level, a sub-district census administrative unit. We matched the roads data to state assembly constituencies. ${ }^{13}$

\section{$5 \quad$ Results}

\subsection{Validity of RD design}

Validity of the RD design requires continuity of predetermined characteristics of constituencies across the threshold of a zero victory margin. We use a rich set of variables determined before the election in $t$, either variables from the previous election in $t-1$, or outcome variables averaged over the previous electoral term. These include the growth of night lights, the share of incomplete road projects, electorate size (i.e. number of registered voters), number of candidates, turnout, female turnout, whether the legislator was a woman, whether the legislator (in $t-1$ ) was an incumbent, whether the head of the winning party

\footnotetext{
${ }^{11}$ The fraction of all mixed-gender elections that are close, at about one-third, is similar to the share of all elections that are close (irrespective of the gender of the top two vote-winners). The number of close elections is 4,727 , which is 28.5 per cent of all elections.

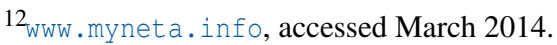

${ }^{13}$ The roads data are at http://omms.nic.in/, accessed May 2015. While there is significant geographical overlap between a census block and an assembly constituency (sharing on average 80 per cent of villages), a census block could span more than one assembly constituency. We assign block-level road variables to an assembly constituency if the constituency contains at least 50 per cent of villages in the block.
} 
was a woman, as well as whether the constituency was reserved for lower castes (Scheduled Castes or Scheduled Tribes), aligned with the state government, and aligned with the central government.

Figure 4 reports graphical evidence of the validity of the continuity assumption. For instance, consider Panel (a) which plots average growth of light output in the previous election term against the margin of victory in $t$. The scatter plot depicts the local averages of growth of light in each successive interval of 0.5 per cent of a margin of victory. The local linear curve is estimated using a triangular kernel and a 5 per cent bandwidth and the 95 per cent confidence interval is shown. The average growth of light in the previous term is a continuous function of the margin of victory. Similarly, we find balance on other constituency characteristics. Overall, the evidence suggests that only the gender of the legislator changes abruptly at the zero margin of victory and that, therefore, we can take the RD design as identifying the causal effect of the election of a woman on economic growth. Table A.4 reports a comparison of means of constituency characteristics in female- versus male-led constituencies in the mixed-gender sample with and without restricting to close elections.

Another potential concern is that there is sorting around the cutoff, which would imply that the winning chances of men and women are not equal even in a close election. Such sorting has been documented in the case of close elections between Republicans and Democrats in the United States, and associated with manipulation of the margin of victory that renders the close election experiment invalid (Caughey and Sekhon 2011; Grimmer et al. 2012; Snyder 2005). To investigate this, Figure 5 depicts the density of the margin of victory as suggested by McCrary (2008). There is no apparent discontinuity in the density around the cutoff. The point estimate of the discontinuity is 0.043 with a standard error of 0.075 . This suggests there is no evidence of sorting in our sample of close mixed-gender races, and female and male candidates are equally likely to win. The figure (Panel a) also shows that the distribution of the margin by which women win is broadly similar to the distribution of the margin by which men win in mixed-gender races. 
Figure 4: Continuity checks

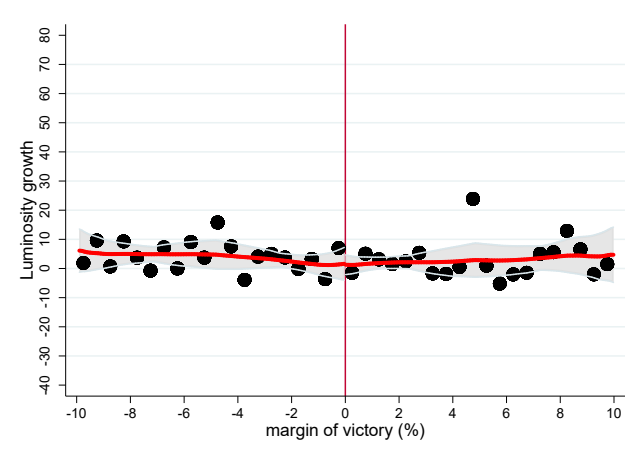

(a) Growth of light in $t-1$

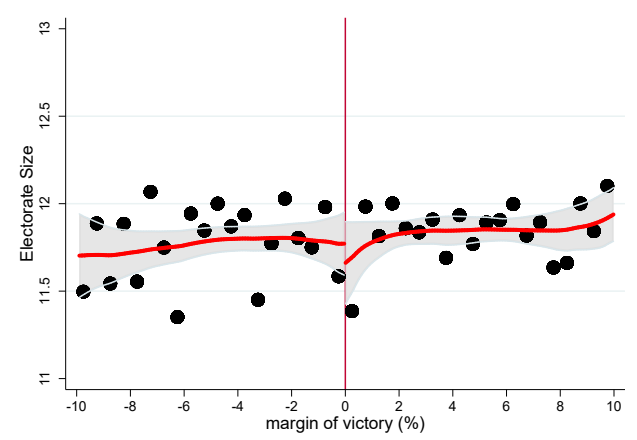

(c) Electorate size in $t-1$

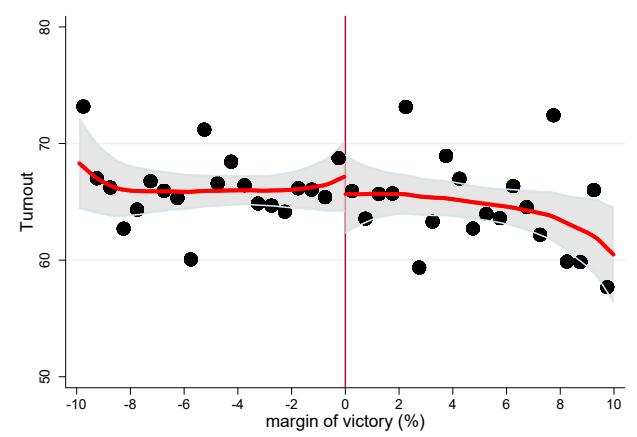

(e) Turnout in $t-1$

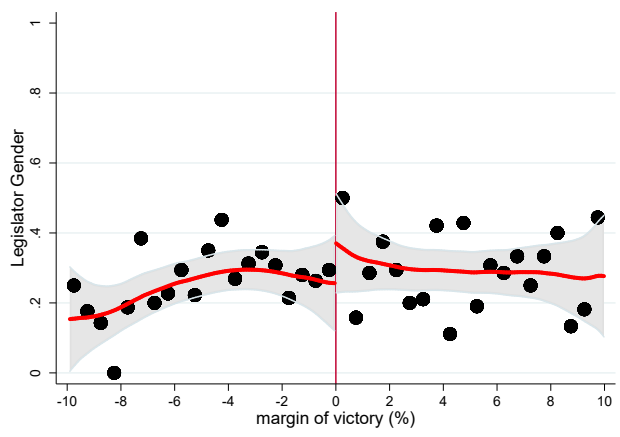

(g) Female legislator in $t-1$

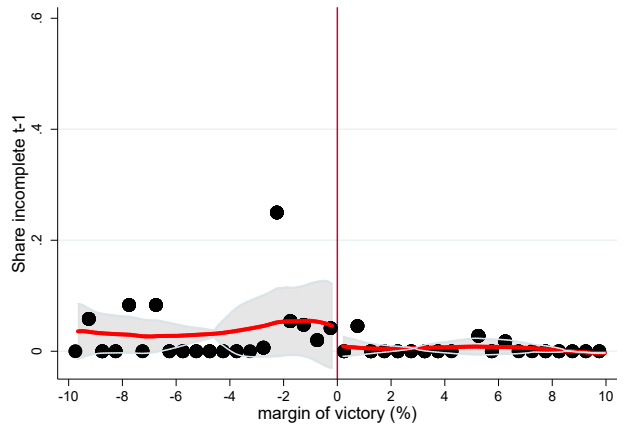

(b) Share incomplete roads in $t-1$

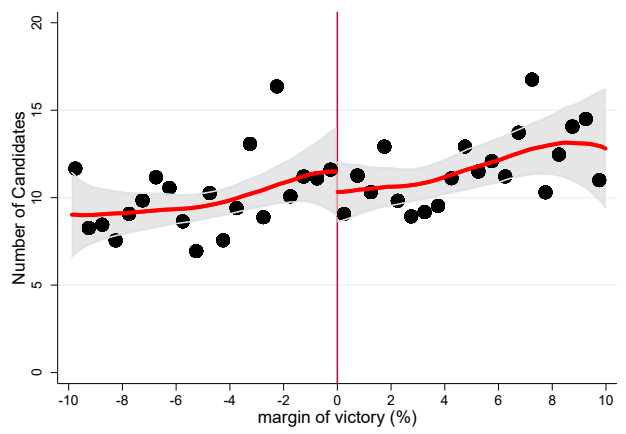

(d) Number of candidates in $t-1$

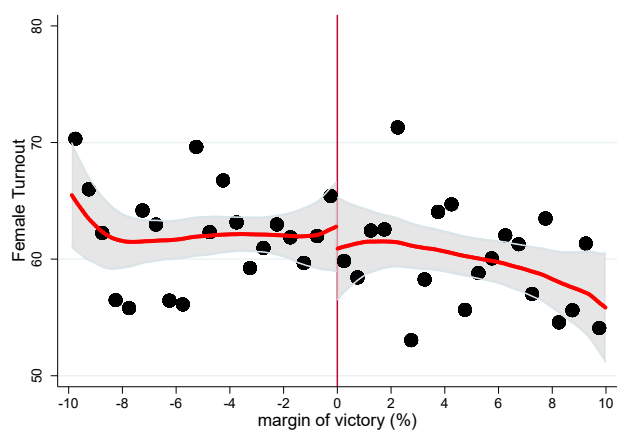

(f) Female turnout in $t-1$

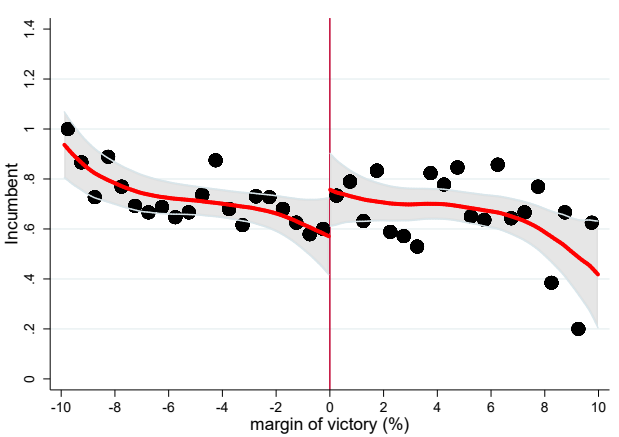

(h) Incumbent in $t-1$ 


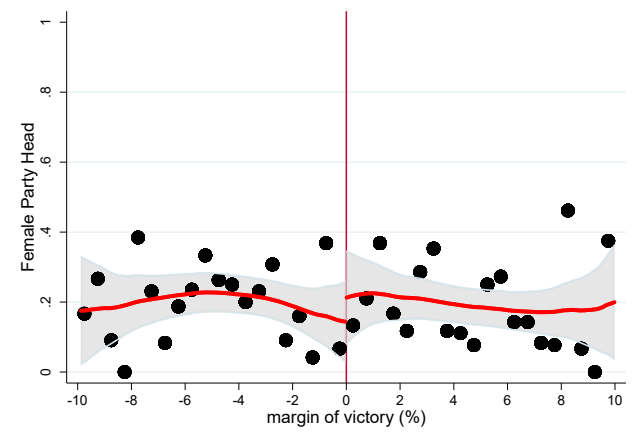

(i) Female party head in $t-1$

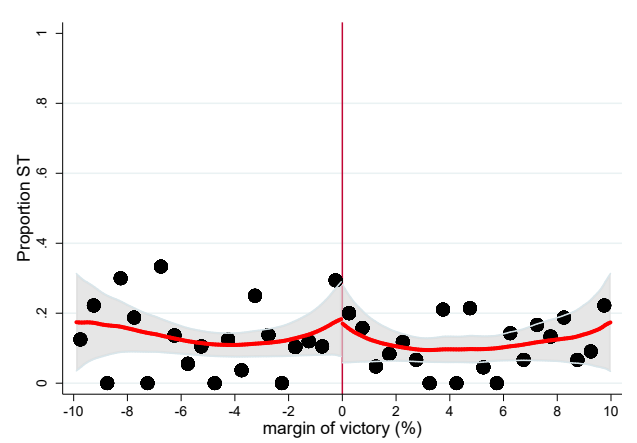

(k) ST-reserved constituency in $t-1$

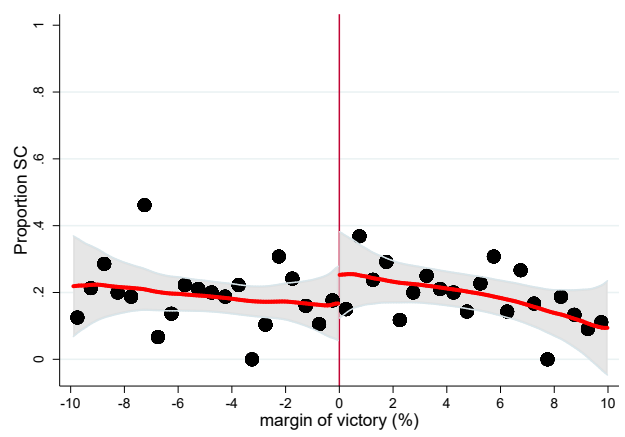

(j) SC-reserved constituency in $t-1$

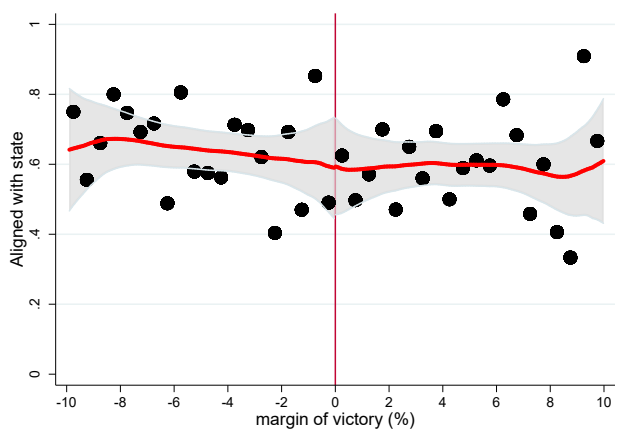

(I) Aligned with state government in $t-1$

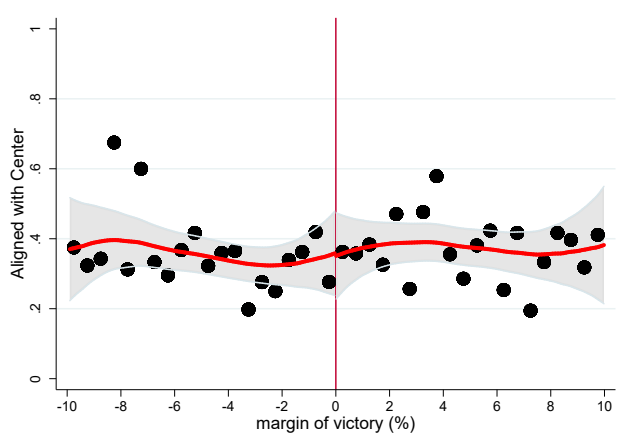

(m) Aligned with central government in $t-1$

Note: Each variable is plotted against the female margin of victory in mixed-gender elections, which is the difference between vote shares of a female candidate and male candidate in mixed-gender elections. Mixed-gender elections are those in which a woman either won or was a runner-up against a man. By construction, margin of victory is positive for female legislators and negative for male legislators. Each dot represents a local average in bins of 0.5 per cent margin of victory. The solid lines are the smooth curves estimated using a local linear regression of each variable on margin of victory separately on either side of the cutoff of zero, triangular kernel, and a 5 per cent bandwidth. The figures also depict a 95 per cent confidence interval for each variable around the solid curve.

Source: authors, based on data from the Election Commission of India, NOAA's National Geophysical Data Centre, and PMGSY's Online Management, Monitoring and Accounting System. 
Figure 5: Density of the forcing variable

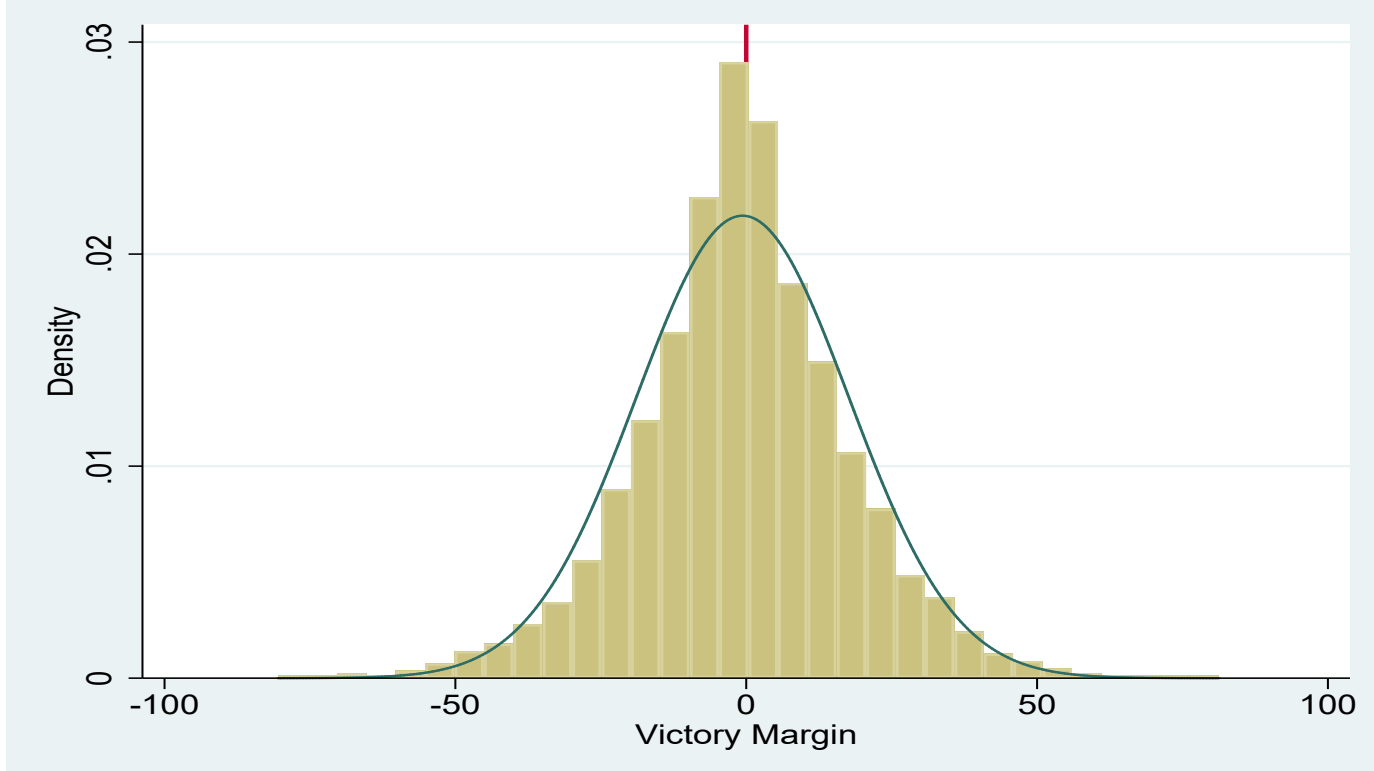

(a) Density of victory margin

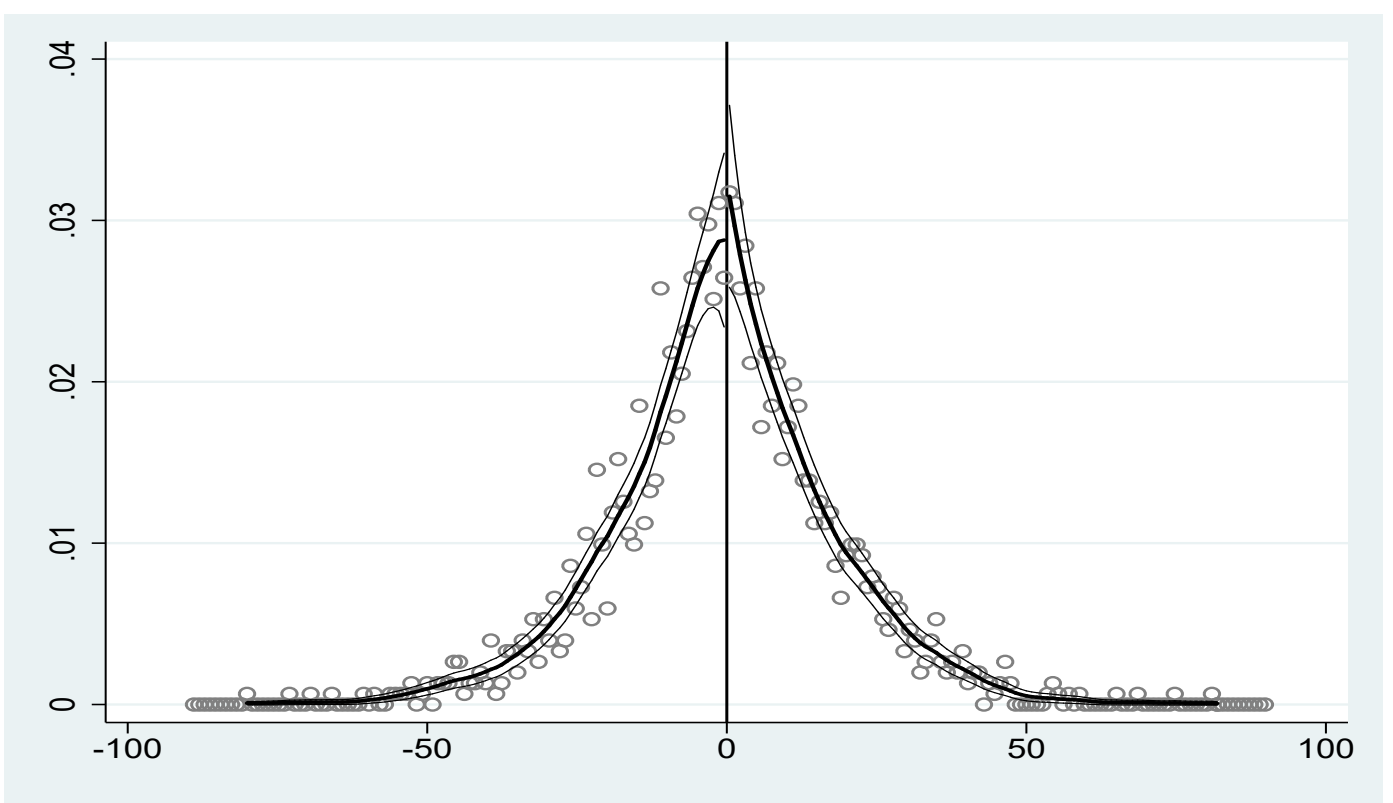

(b) McCrary's density test

Note: The figures plot the density of the margin of victory, which is the difference between vote shares of the female and male candidates in mixed-gender races. Mixed-gender races are defined as those in which a man and a woman rank in the top two. By construction, margin of victory is positive for female legislators and negative for male legislators. The magnitude of the discontinuity (log difference in height) is 0.13 (with a standard error of 0.15 ).

Source: authors, based on the Election Commission of India. 


\subsection{Main results: legislator gender and economic performance}

In this section we present estimates of the causal effect of female relative to male legislators on economic activity over the electoral term in the constituency from which they were elected. The RD estimate of the impact of electing a woman rather than a man is the difference in luminosity at the zero margin of victory. In Figure 6, we plot average growth in luminosity against margin of victory. We average the underlying data across bins that each cover 0.5 percentage points in the margin of victory and provide local linear smoothing of the underlying data using a bandwidth of 5 per cent. We observe a discontinuous jump in light output at the threshold margin of victory of zero, suggesting that female legislators raise economic activity more than do male legislators.

Figure 6: Legislator gender and luminosity growth

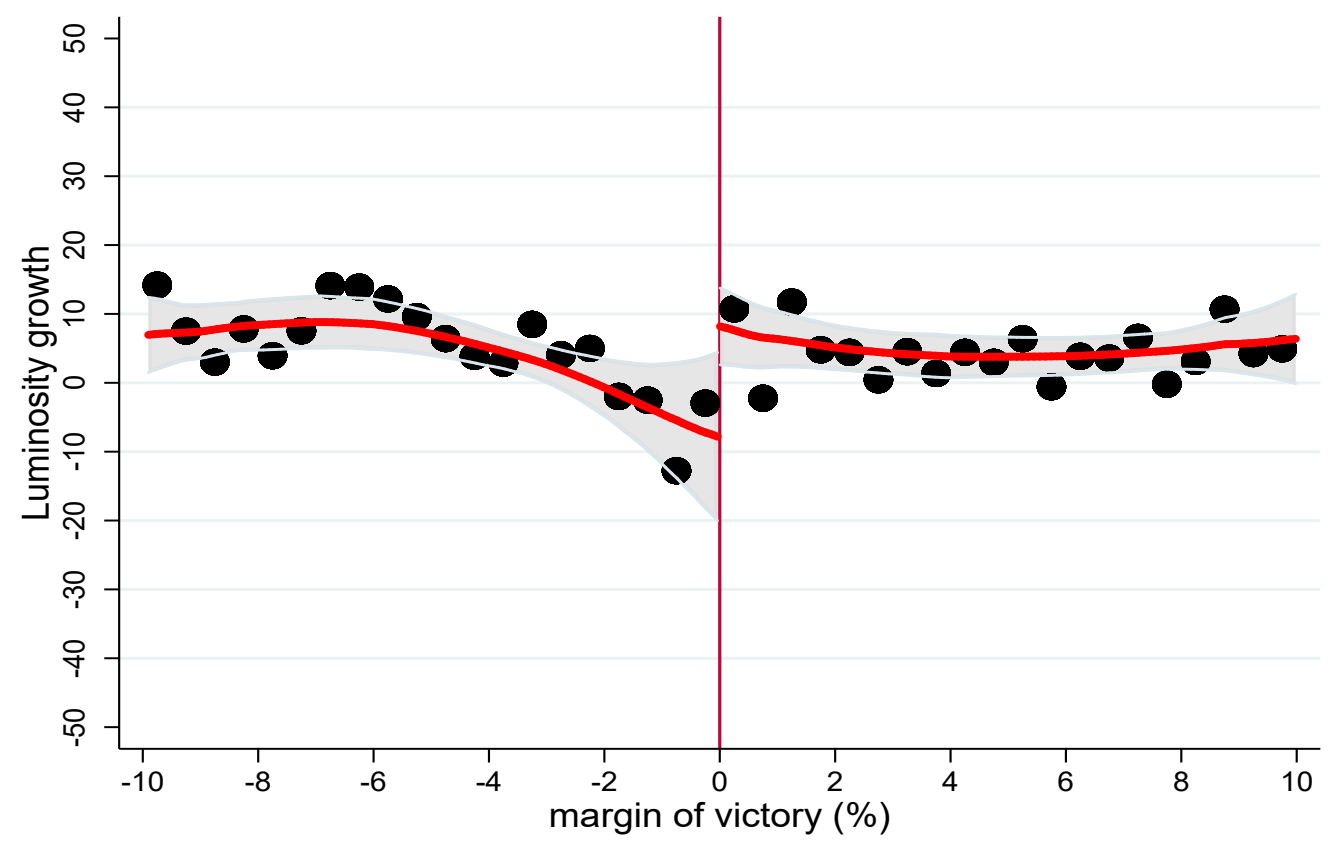

Note: The dependent variable is the growth of light averaged over an election term against the female margin of victory in mixed-gender races. The victory margin is the difference between the vote shares of the female and male candidates in mixed-gender races. These are races in which a man and a woman are the top two vote-winners. By construction, the margin of victory is positive when women win and negative when men win. Each dot represents a local average in bins of 0.5 per cent margin of victory. The solid lines are the smooth curves estimated using a local linear regression of each variable on the margin of victory separately on either side of the cutoff of zero, using a triangular kernel and a 5 per cent bandwidth. The figures also depict a 95 per cent confidence interval for each variable around the solid curve.

Source: authors, based on data from the Election Commission of India and NOAA's National Geophysical Data Centre.

The corresponding regression estimates are in Table 1. We estimate a local linear regression of growth of night lights on the margin of victory in the RD framework. The bandwidth is calculated using the optimal bandwidth procedure suggested by Imbens and Kalyanaraman (2012) (IK). The annual luminosity growth averaged over the electoral term is 15.25 percentage points higher in constituencies in which a woman was elected with a small margin than in constituencies in which a man won with a small margin, and this difference is significant at the 5 per cent level (column 1). Using our estimate (from state-year data) of an elasticity of GDP to night lights of 0.12 (see Table A.3), a 15.25 percentage points difference in growth in light translates into a 1.85 percentage points difference in GDP growth. Given that average growth in India during the period of study was about 7 per cent per year, our estimates indicate that the growth premium for constituencies stemming from their having a female legislator is about 25 per cent. 
Table 1: Legislator gender and luminosity growth

\begin{tabular}{|c|c|c|c|c|c|}
\hline & (1) & (2) & (3) & (4) & (5) \\
\hline & \multicolumn{5}{|c|}{ Growth of Light $t+1$} \\
\hline & \multicolumn{4}{|c|}{ Local linear } & \multirow{2}{*}{$\begin{array}{l}\text { Local } \\
\text { quadratic } \\
\text { IK (h) }\end{array}$} \\
\hline & $\mathrm{IK}(\mathrm{h})$ & $\mathrm{h} / 2$ & $2 \mathrm{~h}$ & $\begin{array}{l}\text { IK (h) with } \\
\text { Covariates }\end{array}$ & \\
\hline Female $\mathrm{MLA}_{t}$ & $\begin{array}{l}15.25^{\star *} \\
{[6.12]}\end{array}$ & $\begin{array}{l}16.97^{*} \\
{[8.96]}\end{array}$ & $\begin{array}{l}8.52^{* *} \\
{[3.79]}\end{array}$ & $\begin{array}{l}10.53^{\star *} \\
{[4.40]}\end{array}$ & $\begin{array}{l}17.11^{*} \\
{[9.42]}\end{array}$ \\
\hline $\mathrm{R}^{2}$ & 0.03 & 0.03 & 0.02 & 0.75 & 0.03 \\
\hline$N$ & 584 & 316 & 980 & 428 & 584 \\
\hline Bandwidth & 6.68 & 3.34 & 13.36 & 6.68 & 6.68 \\
\hline
\end{tabular}

Note: The dependent variable is the growth of light, $\left(\log \left(\operatorname{Light}_{t+1}+1\right)-\log \left(\operatorname{Light}_{t+1}\right)\right) \times 100$, per year (averaged over an election term). Female $\mathrm{MLA}_{t}$ is a dummy variable which is 1 for a female legislator and 0 for a male legislator in mixed-gender races in which a female either won or was a runner-up against a male. Column (1) reports estimates from a local linear regression of Growth of Light $t_{t+1}$ on Female MLA $_{t}$, using a bandwidth determined by Imbens and Kalyanaraman's (2012) optimal bandwidth calculator. The forcing variable is margin of victory $\left(\operatorname{margin}_{t}\right)$, which is the difference between vote shares of the female and male candidates. Columns (2) and (3) halve and double the optimal bandwidth. Column (4) additionally controls for the predetermined covariates, constituency and time fixed effects. The predetermined covariates are: Log Electors $t-1$, Number Candidates $t-1$, Turnout $t-1$, Female Turnout $t-1$, Female MLA $t-1$, Incumbent $t-1$, Female Party Head $t-1$, SC-reserved Constituency $t-1$, ST-reserved Constituency $t-1$, Aligned with state government $t-1$, Aligned with central government $t-1$. Column (5) uses a local quadratic smoothing function. The kernel used is triangular. The following it true for this and all subsequent tables unless noted otherwise. The standard errors are clustered at the constituency level. The number of observations within the given bandwidth is denoted by $N$. The symbols *, **, and *** indicate significance at the 10 , 5 , and 1 per cent levels, respectively.

Source: authors, based on data from the Election Commission of India and NOAA's National Geophysical Data Centre.

Sensitivity to bandwidth. We investigated sensitivity of our result to bandwidth choice. Estimates using bandwidths that are half and twice the size of the optimal bandwidth are given in columns (2)-(3). The estimated coefficient declines as the bandwidth increases, but the coefficients in these alternative specifications continue to be similar to the coefficient using the optimal bandwidth. We then revert to the IK optimal bandwidth but control for the predetermined covariates considered in Figure 4 and constituency and year fixed effects (column (4)). The coefficient is again similar. Finally, in column (5) we report results with a second-order local polynomial smoother. Gelman and Imbens (2014) argue against the use of polynomials in $\mathrm{RD}$ of higher order than the quadratic. The estimated treatment effect is only slightly larger than that estimated with a local linear control function.

Beyond bandwidth. Looking to the left of the zero victory margin threshold in Figure 6, we observe higher light growth in the region outside the IK bandwidth, left of about -6 on the horizontal axis. This indicates that men who win by a narrow margin against women achieve lower growth than men who win by a wide margin against women. It also suggests that for a large enough victory margin, men do as well as women although, notably, no better: the curve further left of -6 representing men who win with big margins is about level with the curve to the right of the threshold which represents women winning. This does not challenge our strategy or our findings because the rising part of the curve on the left is outside the optimal bandwidth, and the reason to use the RD design is of course that we expect there is selection in regions far from the zero margin threshold. In other words, a comparison of the growth performance of men and women far from the threshold is potentially confounded by differences in the constituencies in which they win. However, motivated by the dip, we removed from the sample constituency-election years which had either very high or low growth rates of luminosity. The RD plot with these outliers 
Table 2: Robustness tests

\begin{tabular}{|c|c|c|c|c|}
\hline & (1) & (2) & (3) & (4) \\
\hline & \multicolumn{4}{|c|}{ Growth of Light $t+1$} \\
\hline & \multicolumn{4}{|l|}{ Local Linear } \\
\hline & $\begin{array}{l}\text { Without out- } \\
\text { liers }\end{array}$ & $\begin{array}{l}\text { With al- } \\
\text { ternative } \\
\text { margin }\end{array}$ & $\begin{array}{l}\text { Neighbour } \\
\text { sample }\end{array}$ & $\begin{array}{l}\text { Party affilia- } \\
\text { tion }\end{array}$ \\
\hline Female $M L A_{t}$ & $\begin{array}{l}7.18^{\star *} \\
{[3.61]}\end{array}$ & $\begin{array}{l}14.78^{\star \star *} \\
{[5.50]}\end{array}$ & $\begin{array}{l}15.52^{* *} \\
{[6.54]}\end{array}$ & $\begin{array}{l}13.52^{\star *} \\
{[5.90]}\end{array}$ \\
\hline INC & & & & $\begin{array}{l}6.32^{\star \star} \\
{[2.69]}\end{array}$ \\
\hline BJP & & & & $\begin{array}{l}1.79 \\
{[3.44]}\end{array}$ \\
\hline $\mathrm{R}^{2}$ & 0.02 & 0.02 & 0.03 & 0.04 \\
\hline$N$ & 568 & 685 & 553 & 584 \\
\hline Bandwidth & 6.61 & 7.55 & 7.4 & 6.68 \\
\hline
\end{tabular}

Note: The dependent variable in Models (1), (2), and (4) is the growth of light, $\left(\log \left(\operatorname{Light}_{t+1}+1\right)-\log \left(\operatorname{Light}_{t+1}\right)\right) \times 100$, per year, averaged over an election term. In Model (3) for each constituency, the dependent variable is defined as the average growth of light, $\left(\log \left(\operatorname{Light}_{t+1}+1\right)-\log \left(\operatorname{Light}_{t+1}\right)\right) \times 100$ in neighbouring constituencies, averaged over an election term. Model (1) drops constituency election terms with growth of light above and below 100 per cent. Model (2) uses a forcing variable that is defined as the difference between vote shares of the top-placed female and top-placed male candidates (irrespective of whether they are the top two candidates or not). Model (3) uses a sample that only consists of the female-led constituencies and their neighbours. The neighbours are defined as the constituencies that share boundaries with any female-led constituencies. See the paper for details. Model (4) controls for the party of the MLA by means of two dummies that are 1 if the MLA belongs to the INC (Congress Party) or the BJP, respectively. See also Notes to Table 1.

Source: authors, based on data from the Election Commission of India and NOAA's National Geophysical Data Centre.

removed is shown in Figure A.1 and the corresponding RD regression in column (1) of Table 2, which shows that the coefficient, while smaller, remains positive and significant. ${ }^{14} 15$

All mixed-gender elections.As a further sensitivity test, following Meyerson (2014), we estimated regressions with a larger sample that includes all mixed-gender elections in which a woman contested, rather than just elections in which a woman ranked among the top two. The margin of victory is again defined as the difference in the vote shares of the top-ranked female and the top-ranked male candidates, except that now the top-ranked female may not be one of the top two vote-winners. ${ }^{16}$ The results are similar to those in Table 1; see column (2) of Table 2 . This is because the victory margin in the additional races that are incorporated is likely to be away from the discontinuity and hence unlikely to influence estimates that exploit variation around the threshold of a zero victory margin.

\footnotetext{
${ }^{14}$ Outlying growth rates were identified as larger than 100 or -100 per cent. The analysis sample of elections in which a man and a woman are among the top two vote-winners contains 1,623 constituency-year observations. Of these, 20 observations are outliers according to our criteria. Of the 584 observations that are within the IK bandwidth in our estimation sample, ten are outliers.

${ }^{15} \mathrm{As}$ the slight curve to the left of the threshold is of descriptive interest, we examined pre-election characteristics of both candidates and constituencies using the sample of mixed-gender races and comparing men who won by a narrow margin defined as 6.68 per cent to correspond to the IK bandwidth with men who won by a wider margin. The characteristics we compare are those we discuss in the tests of balance ( $\mathrm{RD}$ validity). The only significantly different candidate characteristic is that men who win in close elections carry more criminal charges than men who win with wide margins. The significant differences in the pre-election characteristics of the constituencies in which they win are that men who win by narrow margins are more likely to win in constituencies in which the incumbent is a woman legislator (consistent with these being close elections, and with the results of Bhalotra et al. (2017)), the party leader is a woman, and the party is not aligned with the state.

${ }^{16}$ The margin is by construction positive for elections in which women win. The runner-up is typically the top-ranked man, there being very few elections in which the top two vote-winners are women (about 0.5 per cent of all elections in our time period) and negative for races in which men win.
} 
Gender versus party. We may be concerned that we are capturing the effects of party of the winning legislator rather than of their gender. This seems unlikely since women are not significantly more likely to be from any one of the main parties. Nevertheless, to investigate this concern, we included indicators for whether the legislator is from the Congress or the BJP (with all other parties as the omitted category). The estimates are robust to this (column (4) of Table 2).

\section{$6 \quad$ Spillovers}

We have shown that women are more effective than men at increasing growth in their own constituencies. In this section we investigate whether this comes at the cost of lower growth in other constituencies. Specifically, we examine spillovers to contiguous constituencies. All neighbours are in the same state as the index constituency and the vast majority are male-led. Spillovers can, in principle, go in either direction. They may be negative if legislators were playing a zero-sum game with fixed state resources. Alternatively, positive spillovers may arise if, for example, legislators build roads which continue across constituency boundaries, or if road construction in one constituency increases access to markets in neighbouring constituencies. The same applies to electricity networks. Alternatively, successful legislators (women) may encourage yardstick competition, given that previous work suggests that voters evaluate politicians in their jurisdiction by comparing outcomes with those in neighbouring jurisdictions (Besley and Case 1995).

We define the dependent variable as light growth averaged over neighbours of constituency $j$ identified using a constituency map. The mean (standard deviation) number of neighbours of a constituency is 5.8 (1.6). The independent variable of interest is as before: the gender of the legislator in constituency $j$. The sample is still restricted to mixed-gender elections for $j$, and we use the RD approach described for the main analysis. This yields estimates of the difference in light growth in constituencies neighbouring female- versus male-led constituencies. The estimated coefficient is positive, but the difference is not significant, except in column 4 (Table 3). ${ }^{17}$

\footnotetext{
${ }^{17} \mathrm{We}$ investigated spillovers using another strategy as follows. The idea is that if there are significant geographic spillovers, then the difference between the woman-led constituency and her largely male-led neighbours will be smaller than the difference we estimate using the full sample, which includes non-neighbouring male-led constituencies in the notional control group. We re-estimated the main equation, limiting the estimation sample to constituencies with female legislators and their neighbours; see column (3) of Table 2. The estimates are similar to those in Table 1, which suggests the absence of spillovers.
} 
Table 3: Legislator gender and luminosity growth: spillovers to neighbouring constituencies

\begin{tabular}{|c|c|c|c|c|c|}
\hline & (1) & (2) & (3) & (4) & (5) \\
\hline & \multicolumn{5}{|c|}{ Neighbour average growth of Light $t+1$} \\
\hline & \multicolumn{4}{|c|}{ Local linear } & \multirow{2}{*}{$\begin{array}{l}\text { Local } \\
\text { quadratic } \\
\text { IK (h) }\end{array}$} \\
\hline & IK (h) & $\mathrm{h} / 2$ & $2 \mathrm{~h}$ & $\begin{array}{l}\text { IK (h) with } \\
\text { covariates }\end{array}$ & \\
\hline \multirow{2}{*}{$\begin{array}{l}\text { Female } \\
\mathrm{MLA}_{t}\end{array}$} & 2.83 & 0.89 & 1.6 & $4.66^{*}$ & 1.46 \\
\hline & [1.76] & [2.39] & [1.26] & [2.66] & [2.54] \\
\hline$R^{2}$ & 0.01 & 0.01 & 0 & 0.84 & 0.01 \\
\hline$N$ & 576 & 309 & 965 & 426 & 576 \\
\hline Bandwidth & 6.63 & 3.31 & 13.25 & 6.63 & 6.63 \\
\hline
\end{tabular}

Note: For each constituency, the dependent variable is defined as the average growth of light,

$\left(\log \left(\operatorname{Light}_{t+1}+1\right)-\log \left(\operatorname{Light}_{t+1}\right) \times 100\right.$ in neighbouring constituencies, averaged over an election term. See the paper for details. See Notes to Table 1.

Source: authors, based on data from the Election Commission of India and NOAA's National Geophysical Data Centre.

Mechanisms

In this section we attempt to identify differences in characteristics and behaviours of female versus male legislators that may explain the better performance of women legislators in achieving economic growth.

\subsection{Candidate characteristics}

As discussed earlier, data on candidate characteristics are available for elections held during the 20042008 period. Using these data, we compared characteristics of male and female legislators in the analysis sample containing mixed-gender close elections. Graphs are presented in Figure A.2 and a comparison of means in Table A.5.

In the close election sample (and also in the sample of all mixed-gender elections), women legislators are significantly less likely than men to be carrying criminal charges. They are also slightly younger on average. There is no significant difference in other characteristics, including education and wealth.

If the difference in criminality between male and female legislators were to translate into a difference in their chances of winning, then this would be problematic for our identification strategy. We examined this-see Table A.7, which shows that criminality has no significant influence on winning chances in the sample of close mixed-gender elections.

The difference in criminality between women and men is larger in the close election sample. Overall, male legislators are twice as likely to be carrying charges, while in the close election sample about 10 per cent of women legislators have pending charges in contrast to about 32 per cent of men. Conditional on being criminally accused, women legislators have significantly fewer charges than men. ${ }^{18}$

\footnotetext{
${ }^{18}$ The criminal charges here refer to cases in which an indictment or a charge sheet has been filed. The judicial process in India is very slow and most are never convicted. Following Prakash et al. (2014), we define financial crimes as charges pertaining to a loss to the public exchequer. We follow the classification used by the ADR for serious crimes which include assaults, kidnapping, and murders. Significant gender differences in criminality among legislators remain within crime categories. While 12.7 per cent ( 21.8 per cent) of male legislators in a close race carry a financial (serious) charge, only 3.8 per cent (5.7 per cent) of female legislators in a close race face any financial (serious) charges.
} 
Differences in criminality between men and women legislators are consistent with experimental evidence that women are more risk-averse than men (Eckel and Grossman 2008; Fletschner et al. 2010) and more patient (Mastrobuoni and Rivers 2016) since risk-taking and high discount factors are positively associated with crime (Eckel and Grossman 2008).

It seems plausible that legislators with a criminal record are more likely to practise corruption, to have priorities other than economic development, and, possibly, are less likely to provide a stable business environment. A recent paper, using the same criminal charges variable for India, studies the impact of this characteristic on economic activity proxied by luminosity, but without paying any attention to gender (Prakash et al. 2014). These authors find that criminality is associated with a 22 percentage point penalty in luminosity growth. We replicate their results in Panel A of Table A.6, using an expanded list of states, and obtain an estimate for the growth penalty of 16.8 percentage points. Scaling this estimate with the difference in the propensity for criminality between men and women (a 21.8 percentage points difference in our close election sample-see Table A.5), back-of-the-envelope calculations suggest that the difference in criminality explains about 24 per cent of the growth premium of women.

\subsection{Corruption in office}

Having observed that male legislators are much more likely than female legislators to be carrying pending criminal charges when they stand for election, we also investigate whether they are more corrupt while in office. Politicians in office face stricter scrutiny and are subject to a re-election constraint, which may encourage them to act in more accountable ways. Alternatively, they may develop a sense of duty once they attain office if 'office ennobles' (Bénabou and Tirole 2003; Brennan and Pettit 2002).

Following Fisman et al. (2014), we use growth in net assets (total assets minus total liabilities) during office as a proxy for corruption. Since assets and liabilities are only recorded in the affidavit data that candidates submit when standing for election, Fisman et al. (2014) restrict the estimation sample to candidates who contest for two consecutive elections, whether or not they win. They then compare asset growth for winners with asset growth for runners-up in close races. They acknowledge the selection issues that arise with this sample restriction in some detail, and after a fairly comprehensive assessment, they conclude that analysis of this sample provides useful insight. They find that Indian state legislators who are elected into office with a narrow margin witness a larger growth in net assets through their five-year tenure than do candidates who came close but did not win, estimated as a difference of 3-5 per cent per annum. They interpret this as evidence that politicians leverage public office for private benefits by engaging in rent-seeking activities.

Fisman et al. (2014) do not distinguish between male and female legislators. We adopt their strategy but rather than compare winners with runners-up in close races, we compare women who won in a close race with men who won in a close race. In Figure 7 we plot growth of net assets between elections $t+1$ and $t$ against the margin of victory between winners and losers (of opposite gender) in election $t$. By construction, the margin of victory is positive for female winners and negative for male winners. We find a discontinuity in growth in net assets at the zero margin of victory, indicating lower growth in net assets among female relative to male legislators. Regression estimates are shown in Table 4. Column (1), using the IK bandwidth, shows that net asset growth during an electoral term is about 50 percentage points lower among female legislators. This translates into a 10 percentage point per annum difference in the rate at which male versus female legislators accumulate rents in office. As a benchmark, note that 
the mean annual growth rate of net assets in the sample (averaging over all legislators) is 20 percentage points. ${ }^{19}$

Figure 7: Legislator gender and asset growth

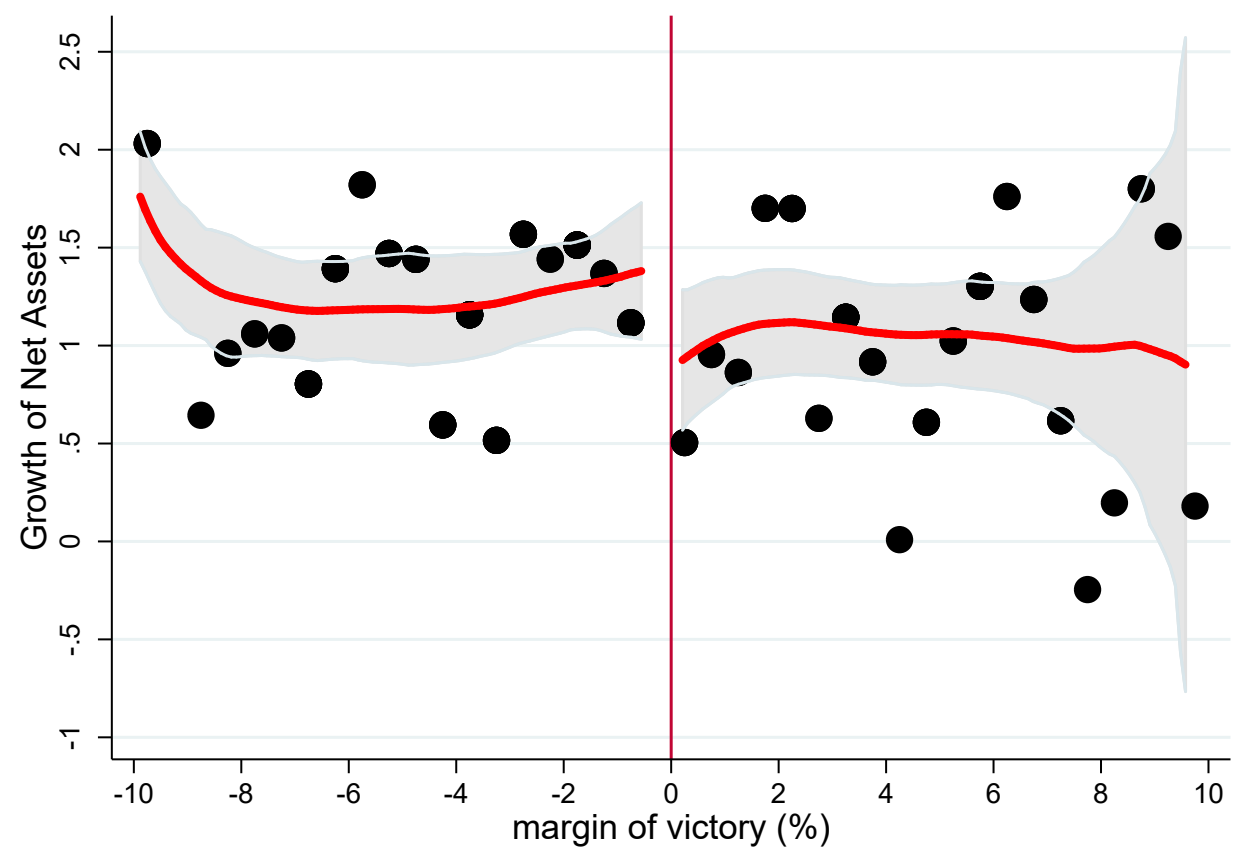

Note: The dependent variable is the growth of net assets plotted against margin of victory, which is the difference between the vote shares of the female and male candidates who rank in the top two vote-winners in mixed-gender elections. The sample is restricted to candidates who re-contest. Each dot represents a local average in bins of 0.5 per cent margin of victory. The solid lines are the smooth curves estimated using a local linear regression of each variable on margin of victory separately on either side of the cutoff of zero, using a triangular kernel and a 5 per cent bandwidth. The figure also depicts a 95 per cent confidence interval for each variable around the solid curve.

Source: authors, based on data from the Election Commission of India.

If we halve the bandwidth, this coefficient is similar but less precisely determined (column (2)). If we double the bandwidth, the coefficient falls to 3 percentage points, suggesting that the difference weakens as we move away from the discontinuity (column (3)). The next two columns show that the result is robust to conditioning on covariates and fixed effects and to replacing the linear with a quadratic polynomial.

Overall, the evidence suggests that women legislators are less likely than men to exploit their office for personal financial gain. It establishes corruption as a likely contributor to the economic advantage of women legislators, given evidence that lower corruption is conducive to economic growth (Dollar et al. 2001; Mauro 1995; Prakash et al. 2014; Swamy et al. 2001). ${ }^{20}$

\footnotetext{
${ }^{19}$ According to Panel A of Table A.2, average asset growth over a five-year term is 100 percentage points in the full sample, so annual asset growth is 20 percentage points.

${ }^{20}$ We have analysed two proxies for corruption—one pertains to the legislator carrying pending criminal charges against them at the time they file their candidacy, and the other to the measure of the rent they accumulate during office if elected. As a coherence check, we confirmed that these two measures are positively associated with one another. Although the coefficient is not statistically significant it is sizeable, (i.e. legislators who entered office carrying criminal charges experience higher net asset growth in office (Panel C of Table A.6)).
} 
Table 4: Legislator gender and asset growth

\begin{tabular}{|c|c|c|c|c|c|}
\hline & (1) & (2) & (3) & (4) & (5) \\
\hline & \multicolumn{5}{|c|}{ Growth of assets } \\
\hline & \multicolumn{4}{|c|}{ Local linear } & \multirow{2}{*}{$\begin{array}{l}\text { Local } \\
\text { quadratic } \\
\text { IK (h) }\end{array}$} \\
\hline & IK (h) & $\mathrm{h} / 2$ & $2 \mathrm{~h}$ & $\begin{array}{l}\text { IK }(\mathrm{h}) \text { with } \\
\text { covari- } \\
\text { ates }\end{array}$ & \\
\hline Female $\mathrm{MLA}_{t}$ & $\begin{array}{l}-0.50 * \\
{[0.25]}\end{array}$ & $\begin{array}{l}-0.61 \\
{[0.45]}\end{array}$ & $\begin{array}{l}-0.03 \\
{[0.28]}\end{array}$ & $\begin{array}{l}-0.48^{\star *} \\
{[0.22]}\end{array}$ & $\begin{array}{l}-0.76^{*} \\
{[0.41]}\end{array}$ \\
\hline $\mathrm{R}^{2}$ & 0.01 & 0.01 & 0 & 0.12 & 0.01 \\
\hline$N$ & 383 & 176 & 734 & 340 & 383 \\
\hline Bandwidth & 3.27 & 1.63 & 6.54 & 3.27 & 3.27 \\
\hline
\end{tabular}

Note: The dependent variable is the average growth rate of net assets over the election term, $\left(\log _{\left(\text {Assets }_{t+1}\right.}+1\right)-$ $\log \left(\right.$ Assets $\left._{t+1}\right)$. The sample is restricted to candidates in mixed-gender races who re-contest. Female $\mathrm{MLA}_{t}$ is a dummy variable which is 1 for a female legislator and 0 for a male legislator. The standard errors are clustered at the state level. See also notes to Table 1.

Source: authors, based on data from the Election Commission of India.

\subsection{Road infrastructure}

We next investigate a hard outcome that is growth-producing. In general and especially in developing countries, road infrastructure is a key ingredient to growth. Rural roads are estimated to have significant positive effects on local economic outcomes, including growth and structural transformation, involving the decline of agricultural work in favour of wage work (Asher and Novosad 2018; Casaburi et al. 2013; Jacoby 2000; Jacoby and Minten 2009; Shrestha forthcoming).

We use administrative data from the PMGSY or Village Road Programme which was launched in 2000 with the goal of providing all-weather access to unconnected habitations across India. The PMGSY is a useful case to analyse for the following reasons. First, it is a massive nationwide programme of considerable political and economic significance. Between 2000 and 2015, it had funded the construction of over $400,000 \mathrm{~km}$ of roads (over 100,000 new roads), benefiting almost 200,000 villages at a cost of almost US $\$ 40$ billion (Asher and Novosad 2018). Second, efficacy of this programme is likely to be a good marker for public goods delivery. Importantly, it involves state legislators bidding for federal funds and delivering goods at the local level. ${ }^{21}$

Programme eligibility involved the village having a population above 1,000 till 2003 and above 500 after that date. Therefore, validity of the RD design we use requires that constituencies won by men versus women in close elections are not systematically different in population size, in particular around these thresholds. Using the 2001 census files, and using both threshold and average population figures at the village level, we test this premise just like we test for continuity across the zero vote margin threshold for other constituency characteristics. The results are in presented in Table A.10 and show no significant differences in population size.

Using data for 2004-2012 and the same RD approach as used for the main analysis, we investigate whether the share of incomplete roads relative to awarded road projects is a function of legislator gender. While we find no significant difference in contracts allocated (Panel B of Table 5), the share of incomplete roads is 22 percentage points lower in constituencies with female legislators (Panel A of

\footnotetext{
${ }^{21}$ PMGSY is federally funded but responsibility for road construction is delegated to state governments, and the programme by definition involves village-level roads. Although eligibility is a function of village-level population, members of parliament and state legislative assemblies are allowed to influence allocation through making suggestions; see Asher and Novosad (2018)).
} 


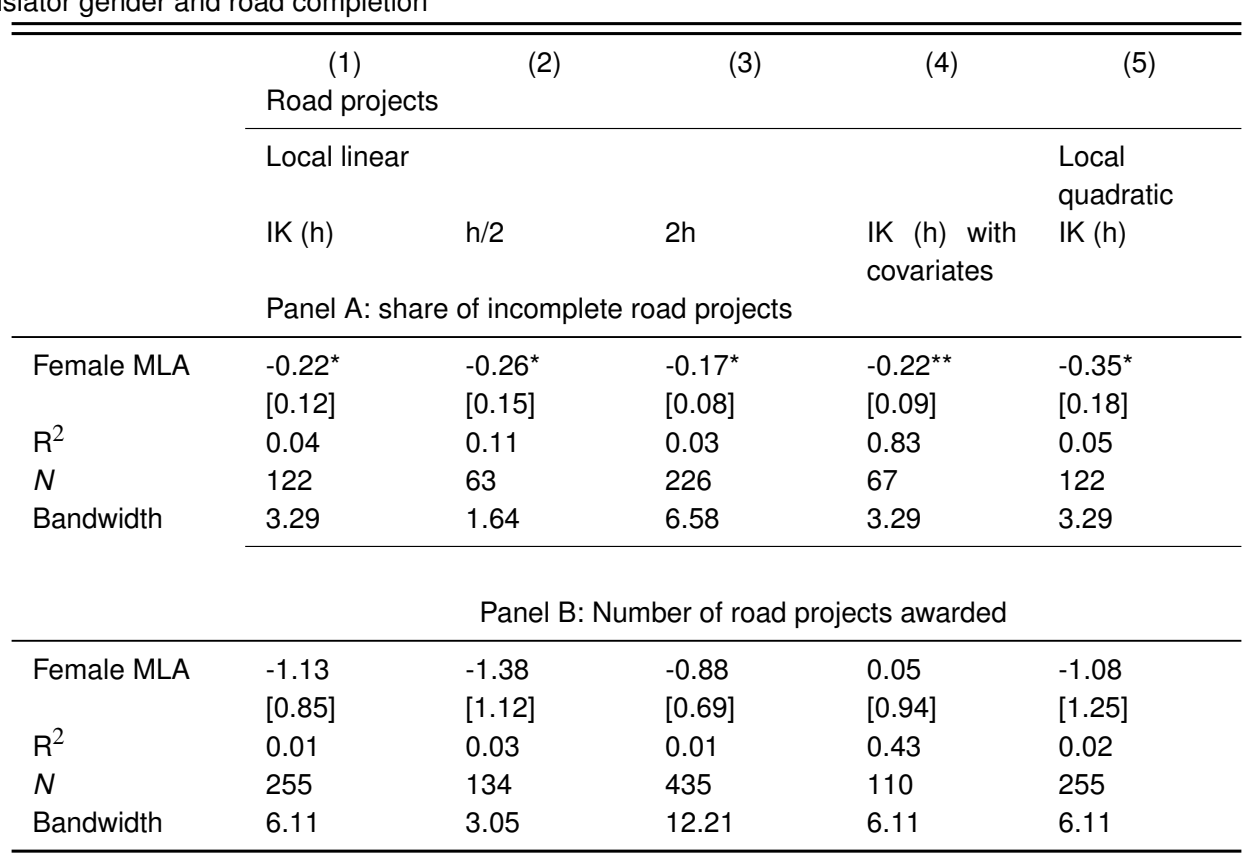

Note: In Panel A, the dependent variable is the share of projects that remain incomplete in total projects awarded, averaged over an election term; in Panel B, the dependent variable is the number of projects awarded. See also notes to Table 1.

Source: authors, based on data from the Election Commission of India and PMGSY's Online Management, Monitoring and Accounting System.

Table 5) than in constituencies with male legislators. This difference is significant across a range of bandwidth choices and robust to inclusion of covariates and to replacing the linear with a quadratic smoother. ${ }^{22}$

For our purposes, this result suggests that women are more effective at completing road projects and hence creating infrastructure for growth. It challenges any presumption that men are more effective at delivering growth-producing infrastructure. More clearly, since road construction in India has been shown to produce higher returns in terms of job mobility for men than for women (Asher and Novosad 2018), our findings establish that women are not only good at serving the interests of women. The qualities that lead women to achieve higher completion rates may include efficiency, mission, or lower corruption, all of which are related to effective delivery of public goods. ${ }^{23}$

\footnotetext{
${ }^{22}$ The mean number of road contracts won (by male and female legislators alike) in the close mixed-gender election sample is 3.5. If an additional fifth of these is left incomplete in male-led constituencies, that implies about 0.7 fewer roads on average. We examined costs associated with a project and found no significant differences in constituencies led by female and male legislators.

${ }^{23}$ Here we report results for roads because we have access to unusually good local-level data on a public infrastructure programme of large political and economic significance. We could not find similar data for other infrastructure. In India, electricity is, like roads, an important state-provided infrastructural good (Lal 2005). Several studies suggest that electricity is the lifeblood of the modern economy (Dinkelman 2011; Lipscomb et al. 2013; Rud 2006) and, in India, power shortages are common and have been shown to significantly reduce output and revenues (Allcott et al. 2014). Moreover, electricity often features as one of the top priorities of Indian voters in election surveys (Chhibber et al. 2004). We measure economic activity using night lights data and it is implicit that this is a proxy for electricity demand. However, to the extent that women legislators better provide electricity (for the same reasons that they better provide roads), some of the better performance of women leaders may reflect better electricity supply.
} 


\subsection{Political opportunism}

A large literature on distributive politics highlights that a drawback of democratic politics is that politicians have an incentive to distort economic policies to pursue a narrow electoral agenda (e.g. Cole (2009); Golden and Min (2013); Mani and Mukand (2007)) and in models of political accountability, politicians are inherently opportunistic, being more likely to exert effort or avoid rent-seeking activities if they face sufficient electoral incentives (Besley and Burgess 2002; Ferejohn 1986).

On the other hand, some politicians may be intrinsically motivated (Brennan and Pettit 2002; Bénabou and Tirole 2003), exerting effort irrespective of the extent of electoral competition. As there are economic costs of opportunism, we investigated whether the weaker growth performance of male legislators could be traced to greater political opportunism among men. We do this by comparing the male-female difference in performance in swing versus core constituencies. The premise is that there are stronger electoral incentives in swing constituencies.

To identify swing and core constituencies, we rely on information on the previous election. We define constituencies where the margin of victory in the previous election was below 5 per cent as swing (i.e. relatively competitive) constituencies and all other constituencies as core constituencies. Around 32 per cent of all constituencies in the close mixed-gender sample are defined as swing according to these criteria. The idea is that constituencies where the margin of victory was close in two consecutive elections (the election that we model as won by men versus women, and the one before) are ceteris paribus more competitive than constituencies where only the most recent election was close.

Results are in Table 6. We estimate the baseline specification (as in Table 1) on the two subsamples of swing and non-swing constituencies with close mixed-gender elections. In swing constituencies, growth does not depend upon the legislator's gender. In contrast, female-led non-swing constituencies have significantly higher growth rates than male-led non-swing constituencies. One explanation of this is that women legislators are less opportunistic and exhibit higher intrinsic motivation. ${ }^{24}$

Notice that, in so far as the behaviour of women in our sample appears not to be driven by the strength of electoral competition, the results in this section suggests external validity of our main findings (which are estimated on a sample of close and hence competitive elections).

\footnotetext{
${ }^{24}$ To the extent that women candidates face systematic prejudice in male-dominated environments such as politics, (EsteveVolart and Bagues 2012; Bhalotra et al. 2017; Casas-Arce and Saiz 2015), women who contest and succeed may be positively selected on unobservables such as motivation or mission.
} 
Table 6: Legislator gender and luminosity growth: swing versus core constituencies

\begin{tabular}{|c|c|c|c|c|c|}
\hline & \multicolumn{4}{|c|}{ Local linear } & \multirow{2}{*}{$\begin{array}{l}\text { Local } \\
\text { quadratic } \\
\text { IK (h) }\end{array}$} \\
\hline & $\mathrm{IK}(\mathrm{h})$ & $\mathrm{h} / 2$ & $2 \mathrm{~h}$ & $\begin{array}{l}\text { IK (h) with } \\
\text { covariates }\end{array}$ & \\
\hline & \multicolumn{5}{|c|}{ Panel A: Swing constituencies } \\
\hline \multirow{2}{*}{$\begin{array}{l}\text { Female } \\
M L A_{t}\end{array}$} & 3.9 & 8.11 & 2.84 & -1.97 & 7.12 \\
\hline & [7.23] & [16.12] & [4.14] & [2.99] & [16.44] \\
\hline $\mathrm{R}^{2}$ & 0.01 & 0.01 & 0.01 & 0.36 & 0.01 \\
\hline$N$ & 234 & 132 & 328 & 201 & 234 \\
\hline \multirow[t]{2}{*}{ Bandwidth } & 10.59 & 5.3 & 21.18 & 21.18 & 10.59 \\
\hline & \multicolumn{5}{|c|}{ Panel B: Non-swing constituencies } \\
\hline \multirow{2}{*}{$\begin{array}{l}\text { Female } \\
M L A_{t}\end{array}$} & $13.76^{\star \star}$ & $16.13^{*}$ & 7.26 & $9.27^{\star}$ & $16.36^{\star}$ \\
\hline & [6.56] & [8.83] & [4.58] & [5.11] & [9.45] \\
\hline $\mathrm{R}^{2}$ & 0.03 & 0.03 & 0.01 & 0.38 & 0.03 \\
\hline$N$ & 387 & 217 & 648 & 329 & 387 \\
\hline Bandwidth & 7.87 & 3.94 & 15.75 & 15.75 & 7.87 \\
\hline
\end{tabular}

Note: Swing constituencies are constituencies in which the margin of victory was below 5 per cent in the previous election. Covariates in Column (4) include predetermined variables, state, and time fixed effects. We omit the constituency fixed effects in Column (4) due to insufficient within-constituency variation in the subsamples. See notes to Table 1.

Source: authors, based on data from the Election Commission of India and NOAA's National Geophysical Data Centre.

\section{$8 \quad$ Extensions}

In this section we investigate differences in the relative performance of male and female legislators in subsamples distinguished by party alignment and gender of the state minister, the education of the legislator, and an indicator of human development (a correlate of corruption) at the state level.

\subsection{Party alignment and gender of state minister}

The evidence suggests that state governments may have an incentive to favour aligned politicians when they allocate public resources (Asher and Novosad 2017; Brollo and Nannicini 2012). Thus, aligned legislators may have more resources to work with, and if women legislators make better use of these resources, this will reinforce their positive effect on growth.

We investigated heterogeneity by alignment (i.e. whether women do better than men in constituencies that are versus are not aligned with the state). ${ }^{25}$ See Table A.8. We find that the difference between female and male legislators is larger in the aligned sample, but not statistically significantly different from the unaligned sample.

If female chief ministers favour female legislators, this may contribute to their relative success. To investigate this, we estimate the baseline RD specification with subsamples of states ruled by female versus male chief ministers. The results are presented in Table A.8. We find no significant difference

\footnotetext{
${ }^{25}$ Note that the alignment status of a constituency may change within a term (e.g. if a coalition at the state level breaks down). To account for this fact in our definition of the alignment dummy, we set the alignment dummy to 1 only for those constituencies that were aligned throughout the term.
} 
in growth by legislator gender in the roughly 15 per cent of constituencies with female chief ministers. The sample is small but the coefficient is not just imprecise, but small. We therefore see no evidence of favouritism along the lines of gender. The sample with male chief ministers (the overwhelming majority of states) exhibits a difference in favour of female legislators similar to the full sample results.

\subsection{Education of legislator}

We showed earlier that there is on average no significant difference in the level of education of female and male legislators in the close mixed-gender sample. So education is unlikely to be a mechanism. However, given an interest in the relationship between politician education and policy choices (Besley et al. 2011), we investigate whether the relative success of women emerges from samples of more or less educated legislators.

We separate the sample into constituencies led by legislators with and without a college education; see Table A.8. We find that growth in luminosity is only higher for women-led constituencies in the sample in which leaders have less than college education.

One explanation for this result that is consistent with our discussion of mechanisms is that male-female differences in criminality are greater in this sample. In both samples (with and without college education) the share of women legislators carrying criminal charges is similar (13 versus 14 per cent). However, the share of men with criminal charges is larger among non-college-educated legislators, at 32 per cent versus 25 per cent. ${ }^{26}$

\subsection{Institutional environment}

If clean governance is an important reason that women-led constituencies experience higher growth, we may expect that women make a larger difference in institutional environments where (male-dominated) corruption is pervasive. We investigate this using the Human Development Index (HDI) as a proxy for the prevailing quality of government (Sen and Dreze 2005). We split the sample into the relatively developed versus underdeveloped states based on their HDI, using the median HDI value in 1999 as the threshold. We re-estimate the baseline model on the two subsamples; see Table 7. The result that women are better than men at producing growth is only statistically significant in the less developed states. $^{27}$

One reason for this difference is likely to be that male and female legislators have more similar criminal propensities in the more developed states (recall that we have already shown that they are balanced on other observables, including education and wealth in the analysis sample). However, in the less developed states, male legislators are more likely than female legislators to have criminal histories. They exhibit a 5 percentage point greater likelihood of carrying financial crime charges $(10.7$ per cent versus 15.6 per cent) and a 7 percentage point difference in carrying serious criminal charges ( 23.3 per cent versus 30.6 per cent). In line with this, we show that asset growth in office is higher for men than for women, primarily in the less developed states sample (Table 7). This result is consistent with Fisman

\footnotetext{
${ }^{26}$ The effect size in the sample with less than college education is large and may be driven by influential outliers given that this subsample has only 80 observations.

${ }^{27}$ Although the difference in the two coefficients is not statistically significant, the coefficient is twice as large in the less developed states sample.
} 
Table 7: Legislator gender: results by state-level development

\begin{tabular}{|c|c|c|c|}
\hline & (1) & (2) & (3) \\
\hline & Growth of light & $\begin{array}{l}\text { Share roads } \\
\text { incomplete }\end{array}$ & $\begin{array}{l}\text { Growth of as- } \\
\text { sets }\end{array}$ \\
\hline & \multicolumn{3}{|c|}{ Panel A: Less developed states } \\
\hline \multirow[t]{2}{*}{ Female MLAs } & $20.37^{\star}$ & -0.19 & $-0.73^{\star * *}$ \\
\hline & [10.56] & {$[0.16]$} & [0.22] \\
\hline$R^{2}$ & 0.03 & 0.02 & 0.02 \\
\hline$N$ & 258 & 72 & 251 \\
\hline \multirow[t]{2}{*}{ Bandwidth } & 5.45 & 3.42 & 3.52 \\
\hline & \multicolumn{3}{|c|}{ Panel B: more developed states } \\
\hline \multirow[t]{2}{*}{ Female MLAs } & 9.16 & -0.25 & 0.19 \\
\hline & {$[5.75]$} & {$[0.19]$} & {$[0.25]$} \\
\hline$R^{2}$ & 0.02 & 0.1 & 0.03 \\
\hline$N$ & 322 & 57 & 159 \\
\hline Bandwidth & 8.3 & 3.62 & 3.44 \\
\hline
\end{tabular}

Note: The Human Development Indicator (HDI) for all Indian states in available from a 1999 report. We define a state as less developed if the HDI is less than the median HDI. Based on this definition, the following states are classified as less developed: Andhra Pradesh, Assam, Bihar, Chhattisgarh, Jharkhand, Madhya Pradesh, Orissa, Rajasthan, Uttar Pradesh, and Uttarakhand. All models use the specification in Model (1) of Table 1. See notes to Table 1.

Source: authors, based on data from the Election Commission of India, NOAA's National Geophysical Data Centre, PMGSY's Online Management, Monitoring and Accounting System, and UNDP.

et al. (2014), who found that, in general (i.e. not distinguishing gender of legislator), rents from public office are higher in less developed states.

Overall, these findings are consistent with the results in Section 7, which highlight the relevance of criminal histories and corruption in office in explaining our finding that constituencies led by women legislators exhibit stronger economic performance.

In summary, our findings that the better performance of women legislators stems from the less developed states and from the sample of less educated legislators can be (at least partially) traced to these subsamples exhibiting larger differences by legislator gender in criminal charges and corruption. Comparison of coefficient magnitudes suggests that women are more effective than men when the constituency leader is aligned with the state-level party, but the difference is not statistically significant. There is no evidence that women legislators are more effective when the state chief minister is a woman, so we can reject favouritism between women as a channel for the success of women leaders.

\subsection{External validity}

While RD is regarded as producing consistent or internally valid estimates of causal effects, a common concern is that the estimates may have limited external validity. We assess this in three different ways. First, we refer to previous work for India (Bhalotra et al. 2017), which examines voter preferences for women candidates measured as the vote share obtained by all women contesting in constituencies in which there are close mixed-gender elections. They show that this share ranges from less than 20 per cent to 65 per cent. This wide variation in preferences for female politicians suggests external validity of results from the close sample.

Second, the same authors show that among constituencies that have at least one mixed-gender election, nearly 60 per cent have had only one or two mixed-gender elections over a period of three decades. This 
again points to external validity in as much as it establishes that our RD estimates do not capture features specific to mixed-gender constituencies.

Third, we compare characteristics of constituencies in the sample of mixed-gender elections divided up as close versus non-close elections; see columns (1)-(3) of Table A.9. We find very few differences. Constituencies with close mixed-gender elections are slightly more likely to have a female incumbent and a female party head and less likely to be aligned with the state government. Although the RD design does not require balance on candidate characteristics, for the descriptive purpose of understanding candidate selection into close elections we also compared candidate characteristics in close versus nonclose mixed-gender elections. The only significant difference we find is that, on average, candidates have a larger number of criminal cases in close mixed-gender elections (consistent with our discussion of the external validity of our baseline results in Section 5.2). ${ }^{28}$

We estimated OLS regressions using the universe of elections in India, and panel data identification. We find no significant impact of legislator gender on growth. ${ }^{29}$ As discussed in Section 1, there is similarly no correlation between politician gender and growth (GDP) in cross-country data (see Figure A.3). This suggests negative OLS bias, or that women legislators are in general selectively elected in areas with lower growth potential. Since the causal effect of women on growth is not readily evident in observational data, it is important to investigate this relationship using techniques for causal identification in other settings.

\section{Conclusion}

We estimate that women legislators in India raise luminosity growth in their constituencies by about 15 percentage points per annum more than male legislators. This translates to a difference of about 1.8 percentage points in annual GDP growth. Given that average growth in India during the sample period was about 7 per cent, our estimates indicate that the growth premium for constituencies stemming from their having a female legislator is about 25 per cent. Evidence cited in Section 1 showing that women politicians are more effective at delivering health and primary education (and hence in creating human capital) suggests that the impact of women leaders on long-term growth may be even larger.

We find no evidence of negative spillovers from female-led constituencies. The evidence thus suggests considerable positive overall growth gains. The growth advantage conferred by women leaders is not apparent in observational data from India or from a cross-country database, but is evident once selection into office is accounted for.

We provide, as far as we know, the first causal estimates linking legislator gender to economic activity. A considerable body of evidence has demonstrated that women politicians more effectively represent the interests of women and children. As pro-female and pro-family policies are often associated with welfare payments, one may expect that widening the representation of women in government compromises growth, at least over a period as short as an electoral term. However, no previous work has attempted to investigate this. Our results reject such concerns, establishing that not only is growth unharmed but, indeed, it is enhanced under women's leadership.

\footnotetext{
${ }^{28}$ On the other hand, there are significant differences between candidates and constituencies in mixed-gender versus non-mixed (mostly all-male) races (column (4)-(6) of Table A.9). Candidates in mixed-gender constituencies have a lower propensity for criminality, are younger and slightly less educated. With respect to constituency characteristics, we observe that average light growth in the previous electoral term tends to be smaller in mixed-gender constituencies and that the likelihood of a female legislator being an incumbent is higher.

${ }^{29}$ These results are available upon request.
} 
Investigating mechanisms, we find that women are only about one-third as likely as men to be carrying pending criminal charges when they enter office; their assets grow by about 10 percentage points per annum less while in office (a measure of rent-seeking); and for an equal number of funded village road contracts, the share of incomplete road projects is 22 percentage points lower. We find that women are good for growth only in non-swing constituencies, consistent with male legislators exerting additional effort or averting corruption in swing constituencies in which electoral incentives are stronger. All of these results are consistent with women being less corrupt, more effective, and less opportunistic (in terms of being less responsive to electoral incentives).

Laboratory evidence, cited earlier, suggests that there are inherent differences in preferences between women and men (fairness, altruism, higher risk aversion, lower overconfidence) that are predictive of corrupt or criminal behaviour, and other studies, cited earlier, indicate that women may have stronger intrinsic motivation in occupations that generate public benefits. For these reasons, we may find that women legislators outperform men in many environments. We find some evidence that the gender gap in legislator performance is smaller in the more developed states of India, and in the sample of constituencies in which the legislator has a college education. In both cases, this is consistent with lower criminality and corruption among men in these subsamples, in particular, a smaller gender gap in criminality and corruption. Thus, to the extent that opportunities for corruption are more limited in more developed countries, women may be especially effective relative to men at producing growth in less developed countries. 


\section{References}

Aggarwal, S. (2017). 'Do Rural Roads Create Pathways out of Poverty? Evidence from India.' Hyderabad: Indian School of Business.

Ahern, K. and A. Dittmar (2012). 'The Changing of the Boards: The Impact on Firm Valuation of Mandated Female Board Representation'. Quarterly Journal of Economics, 127: 137-97.

Allcott, H., A. Collard-Wexler, and S.D. O'Connell (2014). 'How do Electricity Shortages Affect Productivity? Evidence from India'. NBER Working Paper 19977. Cambridge, MA: National Bureau of Economic Research.

Anderson, S., P. Francois, and A. Kotwal (2014). 'Clientelism in Indian Villages'. Vancouver, BC: Vancouver School of Economics.

Andreoni, J., and L. Vesterlund (2001). 'Which is the Fair Sex? Gender Differences in Altruism'. Quarterly Journal of Economics, 116: 293-312.

Asher, S. and P. Novosad (2017). 'Politics and Local Economic Growth: Evidence from India'. American Economic Journal: Applied Economics, 9(1): 229-73.

Asher, S. and P. Novosad (2018). 'Market Access and Structural Transformation: Evidence from Rural Roads in India'.

Baskaran, T., B. Min, and Y. Uppal (2015). 'Election Cycles and Electricity Provision: Evidence from a Quasi-Experiment with Indian Special Elections'. Journal of Public Economics, 126: 64-73.

Beaman, L., E. Duflo, R. Pande, and P. Topalova (2006). 'Women Politicians, Gender Bias, and PolicyMaking in Rural India. The State of the World's Children' Background paper. New York: UNICEF.

Beaman, L., R. Pande, and A. Cirone (2012). The Impact of Gender Quotas. Oxford: Oxford University Press.

Besley, T., and R. Burgess (2002). 'The Political Economy of Government Responsiveness: Theory and Evidence from India'. Quarterly Journal of Economics, 117(4), 1415-52.

Besley, T. and A. Case (1995). 'Incumbent Behavior: Vote-seeking, Tax Setting, and Yardstick Competition'. American Economic Review, 85(1), 25-45.

Besley, T. and S. Coate (1997). 'An Economic Model of Representative Democracy'. Quarterly Journal of Economics, 112: 85-114.

Besley, T., J.G. Montalvo, and M. Reynal-Querol (2011). 'Do Educated Leaders Matter?' Economic Journal, 121(554): 205-27.

Besley, T.J., O. Folke, T. Persson, and J. Rincke (2013). 'Gender Quotas and the Crisis of the Mediocre Man: Theory and Evidence from Sweden'. IFN Working Paper 985. Stockholm: Research Institute of Industrial Economics

Bhalotra, S. and I. Clots-Figueras (2014). 'Health and Political Agency of Women'. American Economic Journal: Economic Policy, 6: 164-97.

Bhalotra, S., I. Clots-Figueras, and L. Iyer (2017). 'Path-Breakers? Women's Electoral Success and Future Political Participation'. Economic Journal. https://doi.org/10.1111/ecoj.12492

Bhalotra, S. and M. Umana-Aponte (2015). 'Recession, Women and Work in Africa'. In A. Fosu (ed.), Growth and Institutions in African Development. London: UNU/WIDER and Routledge. 
Bickenbach, F., E. Bode, M. Lange, P. Nunnenkamp, and M. Soder (2013). 'Night Lights and Regional GDPs'. Review of World Economics, 152: 425-47.

Bénabou, R. and J. Tirole (2003). 'Intrinsic and Extrinsic Motivation'. Review of Economic Studies, 70: 489-520.

Brennan, G., and P. Pettit (2002). 'Power Corrupts, but can Office Ennoble?' Kyklos, 55: 157-78.

Brollo, F., and T. Nannicini (2012). 'Tying Your Enemy's Hands in Close Races: The Politics of Federal Transfers in Brazil.' American Political Science Review, 106: 742-61.

Brollo, F., and U. Troiano (2014). 'What Happens When a Woman Wins an Election? Evidence from Close Races in Brazil'. Ann Arbor, MI: University of Warwick and University of Michigan.

Campbell, R. (2004). 'Gender, Ideology and Issue Preference: Is There Such a Thing as a Political Women's Interest in Britain?' British Journal of Politics and International Relations, 6: 20-44.

Casaburi, L., R. Glennerster, and T. Suri (2013). 'Rural Roads and Intermediated Trade: Regression Discontinuity Evidence from Sierra Leone'. http://dx.doi.org/10.2139/ssrn.2161643

Casas-Arce, P. and A. Saiz (2015). 'Women and Power: Unpopular, Unwilling, or Held Back?’ Journal of Political Economy, 123(3): 641-69.

Caughey, D. and J.S. Sekhon (2011). 'Elections and the Regression Discontinuity Design: Lessons from Close U.S. House Races, 1942-2008'. Political Analysis, 19: 385-408.

Chaney, C., M.R. Alvarez, and J. Nagler (1998). 'Explaining the Gender Gap in US Presidential Elections, 1980-1992.' Political Research Quarterly, 51: 311-39.

Chattopadhyay, R., and E. Duflo (2004). Women as Policy Makers: Evidence from a Randomized Policy Experiment in India. Econometrica, 72: 1409-43.

Chen, X. and W.D. Nordhaus (2011). Using Luminosity Data as a Proxy for Economic Statistics. Proceedings of the National Academy of Sciences , 108: 8589-94.

Chhibber, P., S. Shastri, and R. Sisson (2004). 'Federal Arrangements and the Provision of Public Goods in India'. Asian Survey, 44: 339-52.

Clots-Figueras, I. (2012). 'Are Female Leaders Good for Education? Evidence from India'. American Economic Journal: Applied Economics, 4: 212-44.

Cole, S. (2009). 'Fixing Market Failures or Fixing Elections? Agricultural Credit in India.' American Economic Journal: Applied Economics, 1: 219-50.

Dahlerup, D. (2006). Women, Quotas and Politics. New York: Routledge.

Dinkelman, T. (2011). 'The Effects of Rural Electrification on Employment: New Evidence from South Africa'. American Economic Review, 101: 3078-108.

Dollar, D., R. Fisman, and R. Gatti (2001). 'Are Women Really the "Fairer" Sex? Corruption and Women in Government'. Journal of Economic Behavior and Organization, 46: 423-9.

Eckel, C., and P. Grossman (2008). 'Men, Women and Risk Aversion: Experimental Evidence'. In C. Plott and V. Smith (eds), Handbook of Experimental Economics Results. New York: Elsevier.

Edlund, L., and R. Pande (2002). 'Why Have Women Become Left Wing? The Political Gender Gap and the Decline in Marriage'. Quarterly Journal of Economics, 117: 917-61. 
Edlund, L., L. Haider, and R. Pande (2005). 'Unmarried Parenthood and Redistributive Politics'. Journal of the European Economic Association, 2-3: 268-278.

Esteve-Volart, B., and M. Bagues (2012). 'Are Women Pawns in the Political Game? Evidence from Elections to the Spanish Senate'. Journal of Public Economics, 96(3-4): 387-99.

Ferejohn, J. (1986). 'Incumbent Performance and Electoral Control'. Public Choice, 50: 5-25.

Ferreira, F. and J. Gyourko (2014). 'Does Gender Matter for Political Leadership? The Case of US Mayors'. Journal of Public Economics, 112: 24-39.

Fisman, R., F. Schulz, and V. Vig (2014). 'The Private Returns to Public Office'. Journal of Political Economy, 122: 806-62.

Fletschner, D., C. Anderson, and A. Cullen (2010). 'Are Women as Likely to Take Risks and Compete? Behavioural Findings from Central Vietnam'. Journal of Development Studies, 46: 1459-79.

Gagliarducci, S., and D. Paserman (2014). 'The Effect of Female Leadership on Establishment and Employee Outcomes: Evidence from Linked Employer-Employee Data'. Research in Labor Economics, 41: 341-72.

Gelman, A., and G. Imbens (2014). Why High-Order Polynomials Should Not be Used in Regression Discontinuity Designs. NBER Working Paper 20405. Cambridge, MA: National Bureau of Economic Research..

Golden, M., and B. Min (2013). 'Distributive Politics Around the World'. Annual Review of Political Science, 16: 73-99.

Grimmer, J., E. Hirsh, B. Feinstein, and D. Carpenter (2012). 'Are Close Elections Random?' Stanford, CA: Stanford University.

Gupta, B. and A. Mukhopadhyay (2014). 'Local Funds and Political Competition: Evidence from the National Rural Employment Guarantee Scheme in India'. IZA Discussion Paper 8196. Bonn: Institute of Labor Economics

Henderson, J.V., A. Storeygard, and D.N. Weil (2012). 'Measuring Economic Growth from Outer Space'. American Economic Review, 102(2): 994-1028.

Imbens, G., and K. Kalyanaraman (2012). 'Optimal Bandwidth Choice for the Regression Discontinuity Estimator’. Review of Economic Studies, 79(3): 933-59.

Iyer, L., A. Mani, P. Mishra, and P. Topalova (2012). 'The Power of Political Voice: Women's Political Representation and Crime in India'. American Economic Journal: Applied Economics, 4: 165-93.

Jacoby, H.G. (2000). 'Access to Markets and the Benefits of Rural Roads'. Economic Journal, 110: 713-37.

Jacoby, H.G., and B. Minten (2009). 'On Measuring the Benefits of Lower Transport Costs'. Journal of Developing Economies, 89: 28-38.

Jerven, M. (2013). 'For Richer, for Poorer: GDP Revisions and Africa's Statistical Tragedy'. African Affairs, 112: 138-47.

Khemani, S. (2006). 'The Political Economy of Equalization Transfers'. In R. Bahl, J. Martinez, and R. Searle (eds), Fiscal Capacity Equalization and Intergovernmental Transfers. New York: Springer.

Lal, S. (2005). 'Can Good Economics Ever be Good Politics? Case Study of the Power Sector in India'. Economic and Political Weekly, 40(7): 649-56. 
Lee, D.S. (2008). 'Randomized Experiments from Non-Random Selection in U.S. House Elections'. Journal of Econometrics, 142: 675-97.

Lipscomb, M., A.M. Mobarak, and T. Barham (2013). 'Development Effects of Electrification: Evidence from the Topographic Placement of Hydropower Plants in Brazil'. American Economic Journal: Applied Economics, 5: 200-31.

Mani, A., and S. Mukand (2007). Democracy, Visibility and Public Good Provision. Journal of Development Economics, 83: 506-29.

Mastrobuoni, G., and D. Rivers (2016). 'Criminal Discount Factors and Deterrence'. Colchester: University of Essex.

Matsa, D., and A. Miller (2013). 'A Female Style in Corporate Leadership? Evidence from Quotas'. American Economic Journal: Applied Economics, 5: 136-69.

Mauro, P. (1995). 'Corruption and Growth'. Quarterly Journal of Economics, 110(3): 681-712.

McCrary, J. (2008). 'Manipulation of the Running Variable in the Regression Discontinuity Design: A Density Test'. Journal of Econometrics, 142: 698-714.

Meyerson, E. (2014). 'Islamic Rule and the Empowerment of the Poor and the Pious'. Econometrica, 82: $229-69$.

Miller, G. (2007). 'Women's Suffrage, Political Responsiveness, and Child Survival in American History'. Quarterly Journal of Economics, 123: 1287-327.

Min, B. (2015). Power and the Vote. New York: Cambridge University Press.

Osborne, M.J., and A. Slivinski (1996). 'A Model of Political Competition with Citizen-Candidates'. Quarterly Journal of Economics, 111: 65-96.

Prakash, N., M. Rockmore, and Y. Uppal (2014). 'Do Criminally Accused Politicians Affect Economic Outcomes?' Mansfield, CT: University of Connecticut.

Rigon, M., and G.M. Tanzi (2012). 'Does Gender Matter for Public Spending? Empirical Evidence from Italian Municipalities’. Working Paper 862. Rome: Bank of Italy.

Rud, J.P. (2006). 'Electricity Provision and Industrial Development: Evidence from India'. Journal of Development Economics, 97: 352-67.

Sen, A. and J. Dreze (2005). India: Economic Development and Social Opportunity. Oxford: Oxford University Press.

Shrestha, S.A. (forthcoming). 'Roads, Participation in Markets, and Benefits to Agricultural Households: Evidence from the Topography-based Highway Network in Nepal'. Economic Development and Cultural Change.

Snyder, J. (2005). 'Detecting Manipulation in U.S. House Elections'. Los Angeles, CA: UCLA.

Spary, C. (2014). 'Women Candidates and Party Nomination Trends in India: Evidence from the 2009 General Election'. Commonwealth \& Comparative Politics, 52: 109-38.

Svaleryd, H. (2009). 'Women's Representation and Public Spending'. European Journal of Political Economy, 25: 186-98.

Swamy, A., S. Knack, Y. Lee, and O. Azfar (2001). 'Gender and Corruption'. Journal of Development Economics, 64: 25-55. 
Thomas, S. (1991). 'The Impact of Women on State Legislative Policies'. Journal of Politics, 53: 958-76.

Tiwari, D. (2014). 'Electoral Competition and Candidate Wealth in India'. San Diego, CA: University of California, San Diego.

Uppal, Y. (2009). 'The Disadvantaged Incumbents: Estimating Incumbency Effects in Indian State Legislatures'. Public Choice, 138: 9-27. 


\section{Appendix}

Table A.1: Variable definitions and data availability

\begin{tabular}{|c|c|}
\hline Variable & Definition (Years of Data Availability) \\
\hline Growth of Light Density & $\begin{array}{l}{[\log ((\text { Light } \text { Output/Area })+1) i, t+1-\log ((\text { Light } \text { Output/Area })+1) i, t] \times 100} \\
(1992-2012)\end{array}$ \\
\hline Share of Incomplete Projects & Number of incomplete projects / Number of projects awarded (2004-2012) \\
\hline Log Electors & Natural log of number of registered voters (1992-2012) \\
\hline Number Candidates & Number of candidates contesting (1992-2012) \\
\hline Turnout (\%) & Percentage of registered voter turned out to vote (1992-2012) \\
\hline Female Turnout (\%) & Percentage of registered women voter turned out to vote (1992-2012) \\
\hline Female MLA & is 1 if a woman won and 0 otherwise. (1992-2012) \\
\hline Incumbent & is 1 if a candidate is incumbent and 0 otherwise (1992-2012) \\
\hline Female Party Head & is 1 if a party is headed by a woman and 0 otherwise (1992-2012) \\
\hline SC-reserved Constituency & $\begin{array}{l}\text { is } 1 \text { if the constituency is reserved for a Scheduled Caste (SC) candidate and } 0 \\
\text { otherwise (1992-2012) }\end{array}$ \\
\hline ST-reserved Constituency & $\begin{array}{l}\text { is } 1 \text { if the constituency is reserved for a Scheduled Tribe (ST) candidate and } 0 \\
\text { otherwise (1992-2012) }\end{array}$ \\
\hline Aligned with State Govt & $\begin{array}{l}\text { is } 1 \text { if the constituency was aligned with the state ruling party or coalition and } 0 \\
\text { otherwise (1992-2012) }\end{array}$ \\
\hline Aligned with Central Govt & $\begin{array}{l}\text { is } 1 \text { if the constituency was aligned with the central ruling party or coalition and } \\
0 \text { otherwise (1992-2012) }\end{array}$ \\
\hline Criminal & $\begin{array}{l}\text { is } 1 \text { if a candidate has a criminal case pending against him or her and } 0 \text { other- } \\
\text { wise (2004-2012) }\end{array}$ \\
\hline Number of Criminal Cases & Total number of charges against the candidate (2004-2012) \\
\hline Financial Crime Dummy & $\begin{array}{l}\text { is } 1 \text { if a candidate has a criminal case that involves a loss to public exchequer } \\
\text { pending against him or her and } 0 \text { otherwise (2004-2012) }\end{array}$ \\
\hline Serious Crime Dummy & $\begin{array}{l}\text { is } 1 \text { if a candidate has a criminal case that involves a serious charge (as defined } \\
\text { by the ADR) against him or her and } 0 \text { otherwise }(2004-2012)\end{array}$ \\
\hline College Educated & is 1 if a candidate has a college degree or higher and 0 otherwise (2004-2012) \\
\hline MLA Age & Age of an MLA in years (2004-2012) \\
\hline Log Total Assets & $\begin{array}{l}\text { Log(Total Assets }+1) \text { where Total Assets are the self-reported assets in the affi- } \\
\text { davits (2004-2012) }\end{array}$ \\
\hline Log Total Liability & $\begin{array}{l}\text { Log(Total Liabilities }+1) \text { where Total Liabilities are the self-reported liabilities in } \\
\text { the affidavits }(2004-2012)\end{array}$ \\
\hline
\end{tabular}

Source: authors. 
Table A.2: Summary statistics

\begin{tabular}{|c|c|c|c|c|c|c|c|c|c|c|}
\hline & \multicolumn{5}{|c|}{ Full Sample } & \multicolumn{5}{|c|}{ Mixed-Gender Sample } \\
\hline & $\mathbf{N}$ & Mean & SD & $\min$ & $\max$ & $\mathbf{N}$ & Mean & SD & $\min$ & $\max$ \\
\hline \multicolumn{11}{|c|}{ Panel A: Main Outcome Variables } \\
\hline Growth of Light & 15520 & 7.46 & 39.6 & -829.8 & 916.3 & 1623 & 4.40 & 31.6 & -829.8 & 318.2 \\
\hline Share of Incomplete Projects & 4198 & 0.11 & 0.26 & 0 & 1 & 561 & 0.12 & 0.26 & 0 & 1 \\
\hline Growth of Net Assets & 1766 & 1.00 & 0.90 & -5.08 & 5.84 & 232 & 1.11 & 0.84 & -1.06 & 4.04 \\
\hline \multicolumn{11}{|c|}{ Panel B: Predetermined Constituency Characteristics } \\
\hline Log Electors $t-1$ & 12402 & 11.7 & 0.81 & 7.93 & 14.2 & 1377 & 11.8 & 0.61 & 8.76 & 13.1 \\
\hline Number Candidates $t-1$ & 10686 & 11.5 & 13.1 & 1 & 1033 & 1252 & 11.4 & 29.8 & 2 & 1033 \\
\hline Turnout $t-1$ & 12402 & 66.1 & 12.7 & 1.07 & 126.0 & 1377 & 65.3 & 11.7 & 4.48 & 96.1 \\
\hline Female Turnout $t-1$ & 10686 & 60.7 & 13.6 & 0.82 & 100.0 & 1252 & 61.0 & 13.2 & 4.32 & 95.7 \\
\hline Female MLA $t-1$ & 12402 & 0.050 & 0.22 & 0 & 1 & 1377 & 0.27 & 0.44 & 0 & 1 \\
\hline Incumbent $t-1$ & 10686 & 0.72 & 0.45 & 0 & 1 & 1252 & 0.69 & 0.46 & 0 & 1 \\
\hline Female Party Head $t-1$ & 10686 & 0.13 & 0.34 & 0 & 1 & 1252 & 0.16 & 0.37 & 0 & 1 \\
\hline SC-reserved Constituency $t-1$ & 12568 & 0.14 & 0.35 & 0 & 1 & 1393 & 0.20 & 0.40 & 0 & 1 \\
\hline ST-reserved Constituency $t-1$ & 12568 & 0.14 & 0.35 & 0 & 1 & 1393 & 0.13 & 0.33 & 0 & 1 \\
\hline Aligned with State Govt $t-1$ & 12568 & 0.61 & 0.48 & 0 & 1 & 1393 & 0.64 & 0.47 & 0 & 1 \\
\hline Aligned with Central Govt $t-1$ & 12402 & 0.33 & 0.41 & 0 & 1 & 1377 & 0.34 & 0.40 & 0 & 1 \\
\hline \multicolumn{11}{|c|}{ Panel C: Candidate Characteristics } \\
\hline Criminal & 3615 & 0.29 & 0.45 & 0 & 1 & 515 & 0.22 & 0.41 & 0 & 1 \\
\hline Number of Criminal Cases & 2454 & 0.91 & 2.26 & 0 & 29 & 333 & 0.71 & 2.53 & 0 & 29 \\
\hline Financial Crime Dummy & 2442 & 0.12 & 0.32 & 0 & 1 & 333 & 0.087 & 0.28 & 0 & 1 \\
\hline Serious Crime Dummy & 2442 & 0.24 & 0.43 & 0 & 1 & 333 & 0.16 & 0.36 & 0 & 1 \\
\hline College Educated & 2927 & 0.58 & 0.49 & 0 & 1 & 408 & 0.54 & 0.50 & 0 & 1 \\
\hline MLA Age & 3055 & 49.3 & 9.97 & 25 & 84 & 423 & 48.1 & 10.1 & 25 & 80 \\
\hline Total Assets ('000 Rs.) & 3106 & 10771.2 & 31028.5 & 0 & 714083.8 & 430 & 9904.5 & 27855.4 & 0 & 330990.9 \\
\hline Total Liability ('000 Rs.) & 2759 & 1102.6 & 6213.9 & 0 & 192653.3 & 375 & 686.8 & 3232.3 & 0 & 54852.6 \\
\hline
\end{tabular}

Note: Full sample is the sample of the all races during the period 1992-2008. Mixed-gender sample is the sample of races in which a female candidate placed either first or second against a male candidate. The unit of observation is an assembly constituency. Each data point is a constituency-election year observation. For annual data, we compute election term averages. The source of the election data and candidate characteristics, such as criminal records, education, assets, and liabilities, is the Election Commission of India. The source of night lights data is NOAA's National

Geophysical Data Center.

Source: authors, based on data from the Election Commission of India and NOAA's National Geophysical Data Center. 
Table A.3: Luminosity elasticity of GDP growth

\begin{tabular}{lccc}
\hline \hline & $(1)$ & $(2)$ & $(3)$ \\
\hline \hline & \multicolumn{3}{c}{$\log (G D P)$} \\
\cline { 2 - 4 } Log(Light/Area) & $0.79^{* * *}$ & $0.72^{* * *}$ & $0.12^{* *}$ \\
& {$[0.15]$} & {$[0.05]$} & {$[0.05]$} \\
State Fixed Effects & No & Yes & Yes \\
Year Fixed Effects & No & No & Yes \\
$R^{2}$ & 0.49 & 0.98 & 0.998 \\
\hline \hline $\mathrm{N}$ & 474 & 474 & 474 \\
\hline
\end{tabular}

Note: This is a sample of 29 Indian states over the period 1992-2009. The standard errors are clustered at the state level and are in the parentheses. The symbols ${ }^{*},{ }^{* *}$, and ${ }^{* * *}$ indicate significane at the 10,5 , and 1 per cent levels, respectively.

Source: authors, based on data from NOAA's National Geophysical Data Centre and Directorate of Economics \& Statistics of respective state governments, India. 
Table A.4: Balance in constituency characteristics, female versus male legislators

\begin{tabular}{|c|c|c|c|c|c|c|}
\hline & (1) & (2) & (3) & (4) & (5) & (6) \\
\hline & \multicolumn{3}{|c|}{ All mixed-gender races } & \multicolumn{3}{|c|}{$\begin{array}{l}\text { Mixed-gender races within } 5 \text { per cent } \\
\text { margin }\end{array}$} \\
\hline & $\begin{array}{l}\text { Female legisla- } \\
\text { tors }\end{array}$ & $\begin{array}{l}\text { Male legisla- } \\
\text { tors }\end{array}$ & Difference & $\begin{array}{l}\text { Female legisla- } \\
\text { tors }\end{array}$ & $\begin{array}{l}\text { Male legisla- } \\
\text { tors }\end{array}$ & Difference \\
\hline Growth of Light Density t-1 & $\begin{array}{c}3.505 \\
(29.052)\end{array}$ & $\begin{array}{c}6.761 \\
(42.261)\end{array}$ & $\begin{array}{l}-3.256 \\
(2.042)\end{array}$ & $\begin{array}{c}3.048 \\
(30.402)\end{array}$ & $\begin{array}{c}3.511 \\
(30.140)\end{array}$ & $\begin{array}{l}-0.464 \\
(3.200)\end{array}$ \\
\hline Share Incomplete Projects $t-1$ & $\begin{array}{c}0.032 \\
(0.150)\end{array}$ & $\begin{array}{c}0.032 \\
(0.127)\end{array}$ & $\begin{array}{l}-0.000 \\
(0.016)\end{array}$ & $\begin{array}{c}0.003 \\
(0.021)\end{array}$ & $\begin{array}{l}0.047 \\
(0.175)\end{array}$ & $\begin{array}{l}-0.044 \\
(0.027)\end{array}$ \\
\hline Log Electors $t-1$ & $\begin{array}{l}11.825 \\
(0.567)\end{array}$ & $\begin{array}{l}11.777 \\
(0.644)\end{array}$ & $\begin{array}{c}0.047 \\
(0.033)\end{array}$ & $\begin{array}{l}11.815 \\
(0.630)\end{array}$ & $\begin{array}{l}11.818 \\
(0.577)\end{array}$ & $\begin{array}{l}-0.003 \\
(0.061)\end{array}$ \\
\hline Number Candidates $t-1$ & $\begin{array}{l}10.761 \\
(7.300)\end{array}$ & $\begin{array}{c}11.903 \\
(40.533)\end{array}$ & $\begin{array}{l}-1.142 \\
(1.689)\end{array}$ & $\begin{array}{l}10.573 \\
(6.975)\end{array}$ & $\begin{array}{l}10.560 \\
(7.274)\end{array}$ & $\begin{array}{c}0.014 \\
(0.758)\end{array}$ \\
\hline Turnout $t-1$ & $\begin{array}{c}64.993 \\
(12.104)\end{array}$ & $\begin{array}{c}65.580 \\
(11.326)\end{array}$ & $\begin{array}{l}-0.588 \\
(0.632)\end{array}$ & $\begin{array}{c}65.588 \\
(11.542)\end{array}$ & $\begin{array}{c}66.104 \\
(10.427)\end{array}$ & $\begin{array}{l}-0.516 \\
(1.119)\end{array}$ \\
\hline Female Turnout $t-1$ & $\begin{array}{c}60.763 \\
(13.816)\end{array}$ & $\begin{array}{c}61.258 \\
(12.668)\end{array}$ & $\begin{array}{l}-0.494 \\
(0.749)\end{array}$ & $\begin{array}{c}61.192 \\
(13.662)\end{array}$ & $\begin{array}{c}62.262 \\
(12.285)\end{array}$ & $\begin{array}{l}-1.070 \\
(1.374)\end{array}$ \\
\hline Female MLA $t-1$ & $\begin{array}{c}0.305 \\
(0.461)\end{array}$ & $\begin{array}{c}0.238 \\
(0.426)\end{array}$ & $\begin{array}{c}0.066^{* * *} \\
(0.024)\end{array}$ & $\begin{array}{c}0.311 \\
(0.464)\end{array}$ & $\begin{array}{c}0.301 \\
(0.460)\end{array}$ & $\begin{array}{c}0.009 \\
(0.047)\end{array}$ \\
\hline Incumbent $t-1$ & $\begin{array}{c}0.666 \\
(0.472)\end{array}$ & $\begin{array}{c}0.707 \\
(0.455)\end{array}$ & $\begin{array}{l}-0.041 \\
(0.026)\end{array}$ & $\begin{array}{c}0.713 \\
(0.454)\end{array}$ & $\begin{array}{c}0.684 \\
(0.466)\end{array}$ & $\begin{array}{c}0.029 \\
(0.049)\end{array}$ \\
\hline Female Party Head $t-1$ & $\begin{array}{c}0.152 \\
(0.359)\end{array}$ & $\begin{array}{c}0.176 \\
(0.381)\end{array}$ & $\begin{array}{l}-0.024 \\
(0.021)\end{array}$ & $\begin{array}{c}0.201 \\
(0.402)\end{array}$ & $\begin{array}{c}0.202 \\
(0.403)\end{array}$ & $\begin{array}{l}-0.001 \\
(0.043)\end{array}$ \\
\hline SC-reserved Constituency $t-1$ & $\begin{array}{c}0.216 \\
(0.412)\end{array}$ & $\begin{array}{c}0.190 \\
(0.392)\end{array}$ & $\begin{array}{c}0.026 \\
(0.022)\end{array}$ & $\begin{array}{c}0.223 \\
(0.418)\end{array}$ & $\begin{array}{c}0.171 \\
(0.377)\end{array}$ & $\begin{array}{c}0.053 \\
(0.040)\end{array}$ \\
\hline ST-reserved Constituency $t-1$ & $\begin{array}{c}0.113 \\
(0.317)\end{array}$ & $\begin{array}{c}0.137 \\
(0.344)\end{array}$ & $\begin{array}{l}-0.024 \\
(0.018)\end{array}$ & $\begin{array}{c}0.112 \\
(0.316)\end{array}$ & $\begin{array}{c}0.114 \\
(0.318)\end{array}$ & $\begin{array}{l}-0.002 \\
(0.032)\end{array}$ \\
\hline Aligned with State Govt $t-1$ & $\begin{array}{c}0.627 \\
(0.476)\end{array}$ & $\begin{array}{c}0.656 \\
(0.468)\end{array}$ & $\begin{array}{l}-0.030 \\
(0.025)\end{array}$ & $\begin{array}{c}0.593 \\
(0.482)\end{array}$ & $\begin{array}{c}0.619 \\
(0.474)\end{array}$ & $\begin{array}{l}-0.026 \\
(0.049)\end{array}$ \\
\hline Aligned with Central Govt $t-1$ & $\begin{array}{c}0.335 \\
(0.395)\end{array}$ & $\begin{array}{c}0.346 \\
(0.411)\end{array}$ & $\begin{array}{l}-0.012 \\
(0.022)\end{array}$ & $\begin{array}{c}0.390 \\
(0.408)\end{array}$ & $\begin{array}{c}0.322 \\
(0.410)\end{array}$ & $\begin{array}{c}0.068 \\
(0.042)\end{array}$ \\
\hline
\end{tabular}

Note: Columns (1)-(3) compare unconditional means of predetermined constituency variables between female-led constituencies and male-led constituencies in our mixed-gender races sample. Columns (4)-(6) additionally condition the sample to close races that are decided by a margin of 5 per cent or less. Standard deviations in parentheses except in columns (3) and (6), which have standard errors in parentheses. The symbols ${ }^{*},{ }^{* \star}$, and ${ }^{* \star *}$ indicate significance at the 10,5 , and 1 per cent levels from tests of no differences, respectively.

Source: authors, based on data from the Election Commission of India and NOAA's National Geophysical Data Centre. 
Table A.5: Balance in candidate characteristics, female versus male legislators

\begin{tabular}{|c|c|c|c|c|c|c|}
\hline & (1) & (2) & (3) & (4) & (5) & (6) \\
\hline & \multicolumn{3}{|c|}{ All mixed-gender races } & \multicolumn{3}{|c|}{$\begin{array}{l}\text { Mixed-gender races within } 5 \\
\text { per cent margin }\end{array}$} \\
\hline & $\begin{array}{l}\text { Female } \\
\text { legislators }\end{array}$ & $\begin{array}{l}\text { Male leg- } \\
\text { islators }\end{array}$ & Difference & $\begin{array}{l}\text { Female } \\
\text { legisla- } \\
\text { tors }\end{array}$ & $\begin{array}{l}\text { Male legis- } \\
\text { lators }\end{array}$ & Difference \\
\hline Criminal & $\begin{array}{c}0.135 \\
(0.342)\end{array}$ & $\begin{array}{c}0.284 \\
(0.452)\end{array}$ & $\begin{array}{c}-0.149^{* * *} \\
(0.036)\end{array}$ & $\begin{array}{c}0.103 \\
(0.306)\end{array}$ & $\begin{array}{l}0.321 \\
(0.470)\end{array}$ & $\begin{array}{l}-0.218^{* * *} \\
(0.066)\end{array}$ \\
\hline Number of Criminal Cases & $\begin{array}{c}0.250 \\
(0.778)\end{array}$ & $\begin{array}{c}1.154 \\
(3.407)\end{array}$ & $\begin{array}{l}-0.904^{* * *} \\
(0.273)\end{array}$ & $\begin{array}{l}0.170 \\
(0.727)\end{array}$ & $\begin{array}{c}2.055 \\
(5.458)\end{array}$ & $\begin{array}{l}-1.885^{\star *} \\
(0.756)\end{array}$ \\
\hline Financial Crime Dummy & $\begin{array}{c}0.037 \\
(0.188)\end{array}$ & $\begin{array}{c}0.136 \\
(0.344)\end{array}$ & $\begin{array}{c}-0.100^{* * *} \\
(0.031)\end{array}$ & $\begin{array}{c}0.038 \\
(0.192)\end{array}$ & $\begin{array}{c}0.127 \\
(0.336)\end{array}$ & $\begin{array}{l}-0.090^{*} \\
(0.053)\end{array}$ \\
\hline Serious Crime Dummy & $\begin{array}{l}0.098 \\
(0.298)\end{array}$ & $\begin{array}{l}0.213 \\
(0.411)\end{array}$ & $\begin{array}{l}-0.115^{* * *} \\
(0.039)\end{array}$ & $\begin{array}{l}0.057 \\
(0.233)\end{array}$ & $\begin{array}{l}0.218 \\
(0.417)\end{array}$ & $\begin{array}{l}-0.162^{* *} \\
(0.065)\end{array}$ \\
\hline College Educated & $\begin{array}{c}0.503 \\
(0.501)\end{array}$ & $\begin{array}{c}0.577 \\
(0.495)\end{array}$ & $\begin{array}{l}-0.075 \\
(0.049)\end{array}$ & $\begin{array}{c}0.460 \\
(0.502)\end{array}$ & $\begin{array}{c}0.565 \\
(0.499)\end{array}$ & $\begin{array}{l}-0.105 \\
(0.087)\end{array}$ \\
\hline MLA's Age & $\begin{array}{c}46.500 \\
(10.344)\end{array}$ & $\begin{array}{l}49.680 \\
(9.676)\end{array}$ & $\begin{array}{c}-3.180^{* * *} \\
(0.973)\end{array}$ & $\begin{array}{c}45.646 \\
(11.341)\end{array}$ & $\begin{array}{l}48.671 \\
(9.939)\end{array}$ & $\begin{array}{l}-3.025^{*} \\
(1.811)\end{array}$ \\
\hline Total Assets ('000 Rs.) & $\begin{array}{l}12588.207 \\
(37190.682)\end{array}$ & $\begin{array}{c}7504.576 \\
(14978.659)\end{array}$ & $\begin{array}{l}5083.631^{*} \\
(2682.717)\end{array}$ & $\begin{array}{c}7859.415 \\
(13907.696)\end{array}$ & $\begin{array}{c}6061.714 \\
(9860.372)\end{array}$ & $\begin{array}{c}1797.701 \\
(2026.900)\end{array}$ \\
\hline Total Liability ('000 Rs.) & $\begin{array}{c}777.249 \\
(4362.568)\end{array}$ & $\begin{array}{c}605.144 \\
(1653.743)\end{array}$ & $\begin{array}{c}172.105 \\
(334.589)\end{array}$ & $\begin{array}{c}741.619 \\
(2509.085)\end{array}$ & $\begin{array}{c}724.553 \\
(2337.882)\end{array}$ & $\begin{array}{c}17.066 \\
(443.373)\end{array}$ \\
\hline
\end{tabular}

Note: These candidate characteristics are available for elections held between 2004 and 2008 from the self-reported candidate affidavits. There is only election per state during the time period considered. Columns (1)-(3) compare unconditional means of candidate characteristics between female-led constituencies with male-led constituencies in our mixed-gender races sample.

Columns (4)-(6) additionally condition the sample to close races that are decided by a margin of 5 per cent or less. Standard deviations in parentheses except in columns (3) and (6), which have standard errors in parentheses. The symbols ${ }^{*},{ }^{* *}$, and ${ }^{* *}$ indicate significance at the 10,5 , and 1 per cent levels from tests of no differences, respectively.

Source: authors, based on data from the Election Commission of India. 
Table A.6: Impact of criminality of legislator on economic growth

\begin{tabular}{|c|c|c|c|}
\hline & (1) & (2) & (3) \\
\hline & Full Sample & Only males & Only females \\
\hline & \multicolumn{3}{|c|}{ Panel A: growth of light } \\
\hline Criminal & $\begin{array}{c}-16.81^{* *} \\
{[7.86]}\end{array}$ & $\begin{array}{c}-16.32^{* *} \\
{[7.74]}\end{array}$ & $\begin{array}{l}-6.67 \\
{[6.25]}\end{array}$ \\
\hline$R^{2}$ & 0.02 & 0.02 & 0.04 \\
\hline$N$ & 520 & 510 & 36 \\
\hline \multirow[t]{2}{*}{ Bandwidth } & 6.44 & 7.02 & 8.39 \\
\hline & \multicolumn{3}{|c|}{ Panel B: share incomplete } \\
\hline Criminal & $\begin{array}{l}0.15^{\star *} \\
{[0.07]}\end{array}$ & $\begin{array}{l}0.15^{* *} \\
{[0.07]}\end{array}$ & $\begin{array}{c}0.06 \\
{[0.15]}\end{array}$ \\
\hline$R^{2}$ & 0.03 & 0.03 & 0.26 \\
\hline$N$ & 162 & 150 & 17 \\
\hline \multirow[t]{2}{*}{ Bandwidth } & 2.6 & 2.52 & 4.55 \\
\hline & \multicolumn{3}{|c|}{ Panel C: growth of assets } \\
\hline Criminal & $\begin{array}{l}0.21 \\
{[0.16]}\end{array}$ & $\begin{array}{l}0.20 \\
{[0.16]}\end{array}$ & $\begin{array}{l}0.18 \\
{[0.28]}\end{array}$ \\
\hline$R^{2}$ & 0.01 & 0.00 & 0.06 \\
\hline$N$ & 395 & 383 & 32 \\
\hline Bandwidth & 3.43 & 3.52 & 4.76 \\
\hline
\end{tabular}

Note: See notes to Table 1. Criminal is a dummy variable which is 1 for a legislator with any criminal accusation and 0 for a legislator with no accusation. The forcing variable is margin of victory $\left(\operatorname{margin}_{t}\right)$, which is the difference between vote shares of the winning and runner-up candidates in races in which a candidate with criminal accusations either won or was the runner-up against a candidate with no accusations. Column (1) reports estimates from a local linear regression of growth of light (Panel A), share of incomplete roads (Panel B), and growth of assets (Panel C) on the criminal dummy for the full sample for which criminal accusation data are available from 2004 onwards. Columns (2) and (3) report the same results as in column (1) for males and females respectively.

Source: authors, based on data from the Election Commission of India, NOAA's National Geophysical Data Centre, and PMGSY's Online Management, Monitoring and Accounting System.

Table A.7: Probability of winning as a function of criminality

\begin{tabular}{cccc}
\hline \hline & $(1)$ & $(2)$ & $(3)$ \\
\hline \hline \multirow{4}{*}{ Criminal } & $0.107^{* * *}$ & -0.0424 & Probability of winning \\
\cline { 2 - 4 } $\mathrm{N}$ & $(0.0189)$ & $(0.0596)$ & $(0.0669)$ \\
& 2823 & 1227 & 977 \\
& \multicolumn{3}{c}{ Panel A: full sample } \\
Criminal & $0.180^{* * *}$ & 0.0142 & -0.0833 \\
& $(0.0534)$ & $(0.175)$ & $(0.204)$ \\
$\mathrm{N}$ & 342 & 142 & 111 \\
\hline \hline
\end{tabular}

Note: This table estimates the RD effect of being criminally accused on probability of winning. In Panel A, the sample is races in which a candidate with criminal accusations either won or was the runner-up against a candidate with no accusations. In Panel B, the sample is mixed-gender races in which a candidate with criminal accusations either won or was the runner-up against a candidate with no accusations. The dependent variables is a dummy variable which is 1 if a candidate wins and 0 otherwise. Criminal is a dummy variable which is 1 if a candidate has any criminal charges against him or her and 0 otherwise. Source: authors, based on data from the Election Commission of India. 
Table A.8: Legislator Gender and luminosity growth: heterogeneity

\begin{tabular}{|c|c|c|c|c|c|c|}
\hline & \multirow{3}{*}{$\begin{array}{c}\text { (1) } \\
\text { Aligned }\end{array}$} & \multirow{3}{*}{$\frac{(2)}{\text { Non-Aligned }}$} & \multirow{3}{*}{$\begin{array}{l}\quad \quad(3) \\
\text { Female } \\
\text { Chief } \\
\text { Minister }\end{array}$} & & & \\
\hline & & & & (4) & \multirow{2}{*}{$\begin{array}{c}\text { (5) } \\
\text { Educated }\end{array}$} & \multirow{2}{*}{$\begin{array}{c}(6) \\
\text { Not Educated }\end{array}$} \\
\hline & & & & $\begin{array}{l}\text { Male Chief } \\
\text { Minister }\end{array}$ & & \\
\hline Female MLAs & $\begin{array}{c}15.67^{\star * *} \\
{[5.07]}\end{array}$ & $\begin{array}{l}10.66 \\
{[7.71]}\end{array}$ & $\begin{array}{l}-5.33 \\
{[4.75]}\end{array}$ & $\begin{array}{l}17.56^{\star \star \star} \\
{[6.77]}\end{array}$ & $\begin{array}{l}-2.29 \\
{[4.37]}\end{array}$ & $\begin{array}{l}65.95^{\star *} \\
{[28.68]}\end{array}$ \\
\hline$R^{2}$ & 0.04 & 0.02 & 0.04 & 0.03 & 0.02 & 0.21 \\
\hline$N$ & 337 & 332 & 101 & 511 & 121 & 80 \\
\hline Bandwidth & 7.92 & 8.05 & 11.52 & 6.48 & 8.46 & 6.79 \\
\hline
\end{tabular}

Note: See notes to Table 1. Aligned constituencies are constituencies that were aligned with the state government in the election in year $t$. Female chief minister is 1 for the year in a state in which a female is the chief Minister (CM) for at least six months of the year and 0 otherwise. Educated is 1 for an MLA with a college degree and 0 otherwise. All models use the optimal IK bandwidth (the specification follows Column (1) in Table 1.)

Source: authors, based on data from the Election Commission of India and NOAA's National Geophysical Data Centre. 
Table A.9: Balance in constituency and candidate characteristics: close versus non-close and mixed-gender versus non-mixedgender constituencies

\begin{tabular}{|c|c|c|c|c|c|c|}
\hline & (1) & $(2)$ & (3) & (4) & (5) & (6) \\
\hline & \multicolumn{3}{|c|}{ Close vs Non Close } & \multicolumn{3}{|c|}{ Mixed-Gender vs Non-Mixed-Gender } \\
\hline & Close & $\begin{array}{l}\text { Non- } \\
\text { close }\end{array}$ & Difference & $\begin{array}{l}\text { Mixed- } \\
\text { Gender }\end{array}$ & $\begin{array}{l}\text { Non- } \\
\text { Mixed- } \\
\text { Gender }\end{array}$ & Difference \\
\hline \multicolumn{7}{|c|}{ Panel A: Predetermined Constituency Characteristics } \\
\hline Growth of Light Density t-1 & $\begin{array}{c}3.293 \\
(30.222)\end{array}$ & $\begin{array}{c}5.974 \\
(38.854)\end{array}$ & $\begin{array}{l}-2.681 \\
(2.277)\end{array}$ & $\begin{array}{c}5.230 \\
(36.670)\end{array}$ & $\begin{array}{c}7.786 \\
(44.545)\end{array}$ & $\begin{array}{c}-2.556^{\star \star} \\
(1.292)\end{array}$ \\
\hline Share Incompete Projects t- 1 & $\begin{array}{c}0.026 \\
(0.129)\end{array}$ & $\begin{array}{c}0.034 \\
(0.143)\end{array}$ & $\begin{array}{l}-0.008 \\
(0.017)\end{array}$ & $\begin{array}{c}0.032 \\
(0.139)\end{array}$ & $\begin{array}{c}0.047 \\
(0.185)\end{array}$ & $\begin{array}{l}-0.015 \\
(0.011)\end{array}$ \\
\hline Log Electors t-1 & $\begin{array}{l}11.817 \\
(0.601)\end{array}$ & $\begin{array}{l}11.793 \\
(0.613)\end{array}$ & $\begin{array}{c}0.024 \\
(0.037)\end{array}$ & $\begin{array}{l}11.799 \\
(0.610)\end{array}$ & $\begin{array}{l}11.659 \\
(0.829)\end{array}$ & $\begin{array}{c}0.141^{* * *} \\
(0.023)\end{array}$ \\
\hline Number Candidates t-1 & $\begin{array}{l}10.566 \\
(7.128)\end{array}$ & $\begin{array}{c}11.679 \\
(34.992)\end{array}$ & $\begin{array}{l}-1.114 \\
(1.868)\end{array}$ & $\begin{array}{c}11.362 \\
(29.828)\end{array}$ & $\begin{array}{l}11.566 \\
(8.728)\end{array}$ & $\begin{array}{l}-0.204 \\
(0.394)\end{array}$ \\
\hline Turnout t-1 & $\begin{array}{c}65.868 \\
(10.941)\end{array}$ & $\begin{array}{c}65.087 \\
(11.975)\end{array}$ & $\begin{array}{c}0.781 \\
(0.702)\end{array}$ & $\begin{array}{c}65.306 \\
(11.695)\end{array}$ & $\begin{array}{c}66.241 \\
(12.833)\end{array}$ & $\begin{array}{l}-0.936^{* *} \\
(0.363)\end{array}$ \\
\hline Female Turnout t-1 & $\begin{array}{c}61.770 \\
(12.929)\end{array}$ & $\begin{array}{c}60.726 \\
(13.332)\end{array}$ & $\begin{array}{c}1.045 \\
(0.827)\end{array}$ & $\begin{array}{c}61.024 \\
(13.221)\end{array}$ & $\begin{array}{c}60.690 \\
(13.620)\end{array}$ & $\begin{array}{c}0.334 \\
(0.408)\end{array}$ \\
\hline Female MLA t-1 & $\begin{array}{c}0.306 \\
(0.461)\end{array}$ & $\begin{array}{c}0.255 \\
(0.436)\end{array}$ & $\begin{array}{l}0.050^{*} \\
(0.027)\end{array}$ & $\begin{array}{c}0.269 \\
(0.444)\end{array}$ & $\begin{array}{c}0.023 \\
(0.150)\end{array}$ & $\begin{array}{c}0.246^{\star * *} \\
(0.006)\end{array}$ \\
\hline Incumbent t-1 & $\begin{array}{c}0.697 \\
(0.460)\end{array}$ & $\begin{array}{c}0.684 \\
(0.465)\end{array}$ & $\begin{array}{c}0.014 \\
(0.029)\end{array}$ & $\begin{array}{c}0.688 \\
(0.464)\end{array}$ & $\begin{array}{c}0.723 \\
(0.447)\end{array}$ & $\begin{array}{c}-0.036^{* * *} \\
(0.014)\end{array}$ \\
\hline Female Party Head t-1 & $\begin{array}{c}0.202 \\
(0.402)\end{array}$ & $\begin{array}{c}0.150 \\
(0.357)\end{array}$ & $\begin{array}{l}0.052^{\star \star} \\
(0.023)\end{array}$ & $\begin{array}{c}0.165 \\
(0.371)\end{array}$ & $\begin{array}{c}0.131 \\
(0.337)\end{array}$ & $\begin{array}{c}0.034^{\star \star \star} \\
(0.010)\end{array}$ \\
\hline SC-reserved Constituency t-1 & $\begin{array}{c}0.195 \\
(0.397)\end{array}$ & $\begin{array}{c}0.205 \\
(0.404)\end{array}$ & $\begin{array}{l}-0.010 \\
(0.024)\end{array}$ & $\begin{array}{c}0.202 \\
(0.402)\end{array}$ & $\begin{array}{c}0.131 \\
(0.337)\end{array}$ & $\begin{array}{c}0.071^{\star * *} \\
(0.010)\end{array}$ \\
\hline ST-reserved Constituency t-1 & $\begin{array}{c}0.113 \\
(0.317)\end{array}$ & $\begin{array}{c}0.131 \\
(0.337)\end{array}$ & $\begin{array}{l}-0.018 \\
(0.020)\end{array}$ & $\begin{array}{c}0.126 \\
(0.332)\end{array}$ & $\begin{array}{c}0.142 \\
(0.349)\end{array}$ & $\begin{array}{l}-0.016^{\star} \\
(0.010)\end{array}$ \\
\hline Aligned with State Govt t-1 & $\begin{array}{c}0.607 \\
(0.477)\end{array}$ & $\begin{array}{c}0.656 \\
(0.469)\end{array}$ & $\begin{array}{l}-0.049^{*} \\
(0.028)\end{array}$ & $\begin{array}{c}0.642 \\
(0.472)\end{array}$ & $\begin{array}{c}0.604 \\
(0.480)\end{array}$ & $\begin{array}{c}0.039^{* * *} \\
(0.014)\end{array}$ \\
\hline Aligned with Central Govt t-1 & $\begin{array}{c}0.353 \\
(0.410)\end{array}$ & $\begin{array}{c}0.336 \\
(0.402)\end{array}$ & $\begin{array}{c}0.017 \\
(0.024)\end{array}$ & $\begin{array}{c}0.341 \\
(0.404)\end{array}$ & $\begin{array}{c}0.332 \\
(0.406)\end{array}$ & $\begin{array}{c}0.009 \\
(0.012)\end{array}$ \\
\hline Panel B: Candidate Charact & ristics & & & & & \\
\hline Criminal & $\begin{array}{c}0.224 \\
(0.418)\end{array}$ & $\begin{array}{c}0.212 \\
(0.409)\end{array}$ & $\begin{array}{c}0.012 \\
(0.040)\end{array}$ & $\begin{array}{c}0.216 \\
(0.412)\end{array}$ & $\begin{array}{c}0.297 \\
(0.457)\end{array}$ & $\begin{array}{c}-0.082^{\star \star \star} \\
(0.021)\end{array}$ \\
\hline Number of Criminal Cases & $\begin{array}{c}1.130 \\
(4.024)\end{array}$ & $\begin{array}{c}0.507 \\
(1.261)\end{array}$ & $\begin{array}{l}0.623^{\star *} \\
(0.294)\end{array}$ & $\begin{array}{c}0.709 \\
(2.525)\end{array}$ & $\begin{array}{c}0.936 \\
(2.219)\end{array}$ & $\begin{array}{l}-0.228^{*} \\
(0.133)\end{array}$ \\
\hline Financial Crime Dummy & $\begin{array}{c}0.083 \\
(0.278)\end{array}$ & $\begin{array}{c}0.089 \\
(0.285)\end{array}$ & $\begin{array}{l}-0.006 \\
(0.033)\end{array}$ & $\begin{array}{c}0.087 \\
(0.282)\end{array}$ & $\begin{array}{c}0.125 \\
(0.330)\end{array}$ & $\begin{array}{c}-0.038^{\star \star} \\
(0.019)\end{array}$ \\
\hline Serious Crime Dummy & $\begin{array}{c}0.139 \\
(0.347)\end{array}$ & $\begin{array}{c}0.164 \\
(0.372)\end{array}$ & $\begin{array}{l}-0.026 \\
(0.043)\end{array}$ & $\begin{array}{c}0.156 \\
(0.364)\end{array}$ & $\begin{array}{c}0.250 \\
(0.433)\end{array}$ & $\begin{array}{c}-0.094^{\star \star \star} \\
(0.025)\end{array}$ \\
\hline College Educated & $\begin{array}{c}0.515 \\
(0.502)\end{array}$ & $\begin{array}{c}0.554 \\
(0.498)\end{array}$ & $\begin{array}{l}-0.039 \\
(0.053)\end{array}$ & $\begin{array}{c}0.542 \\
(0.499)\end{array}$ & $\begin{array}{c}0.588 \\
(0.492)\end{array}$ & $\begin{array}{l}-0.046^{*} \\
(0.026)\end{array}$ \\
\hline MLA's Age & $\begin{array}{c}47.246 \\
(10.691)\end{array}$ & $\begin{array}{l}48.582 \\
(9.818)\end{array}$ & $\begin{array}{l}-1.336 \\
(1.048)\end{array}$ & $\begin{array}{c}48.147 \\
(10.118)\end{array}$ & $\begin{array}{l}49.473 \\
(9.919)\end{array}$ & $\begin{array}{c}-1.326^{\star *} \\
(0.521)\end{array}$ \\
\hline Total Assets ('000 Rs.) & $\begin{array}{c}6902.366 \\
(11914.105)\end{array}$ & $\begin{array}{c}11338.543 \\
(32770.404)\end{array}$ & $\begin{array}{l}-4436.177 \\
(2867.379)\end{array}$ & $\begin{array}{c}9904.523 \\
(27855.378)\end{array}$ & $\begin{array}{c}10910.411 \\
(31511.198)\end{array}$ & $\begin{array}{l}-1005.888 \\
(1612.232)\end{array}$ \\
\hline Total Liability ('000 Rs.) & $\begin{array}{c}732.233 \\
(2406.121)\end{array}$ & $\begin{array}{c}665.473 \\
(3559.485)\end{array}$ & $\begin{array}{c}66.760 \\
(358.284)\end{array}$ & $\begin{array}{c}686.836 \\
(3232.302)\end{array}$ & $\begin{array}{c}1168.046 \\
(6558.791)\end{array}$ & $\begin{array}{l}-481.209 \\
(345.142)\end{array}$ \\
\hline
\end{tabular}

Note: Columns (1)-(3) compare mixed-gender races in which the victory margin was within 5 per cent with mixed-gender races with a larger victory margin. Columns (4)-(6) compare mixed-gender races with non-mixed-gender races. Mixed-gender races are the sample of races in which a female candidate placed either first or second against a male candidate. Standard deviations in parentheses except in columns (3) and (6), which have standard errors in parentheses. The symbols *, **, and *** indicate significance at the 10,5, and 1 per cent levels from tests of no differences, respectively.

Source: authors, based on data from the Election Commission of India, NOAA's National Geophysical Data Centre, and PMGSY's Online Management, Monitoring and Accounting System. 
Table A.10: RD check for road completion: constituency population thresholds

\begin{tabular}{lclll}
\hline & \multicolumn{1}{c}{$(1)$} & \multicolumn{1}{c}{$(2)$} & \multicolumn{1}{c}{$(3)$} \\
\hline & $\begin{array}{l}\text { Average village } \\
\text { population }\end{array}$ & $\begin{array}{l}\text { Proportion } \\
\text { villages } \\
\text { population } \geq 500\end{array}$ & $\begin{array}{l}\text { of } \\
\text { with }\end{array}$ & $\begin{array}{l}\text { Proportion } \\
\text { villages } \\
\text { population } \geq 1000\end{array}$ \\
with \\
Female MLA $t$ & 155.1 & -0.0764 & 0.00707 \\
Bandwidth & $(500.10)$ & $(0.10)$ & $(0.12)$ \\
$\mathrm{N}$ & 10.7 & 2.27 & 3.23 \\
\hline
\end{tabular}

Note: The village population data are from the 2001 census. Female $\mathrm{MLA}_{t}$ is a dummy variable which is 1 for a female legislator and 0 for a male legislator in mixed-gender races. The forcing variable is margin of victory $\left(\operatorname{margin}_{t}\right)$, which is the difference between vote shares of the winning and runner-up candidates in mixed-gender races. Column (1) reports estimates from a local linear regression of average village population on female $\mathrm{MLA}_{t}$, using a bandwidth determined by Imbens and Kalyanaraman's (2012) optimal bandwidth calculator. The dependent variables are proportion of villages with population of 500 or more in column (2) and proportion of villages with population of 1,000 or more in column (3). The kernel used is triangular and standard errors are in parentheses.

Source: authors, based on data from the Election Commission of India and Census India 2001. 


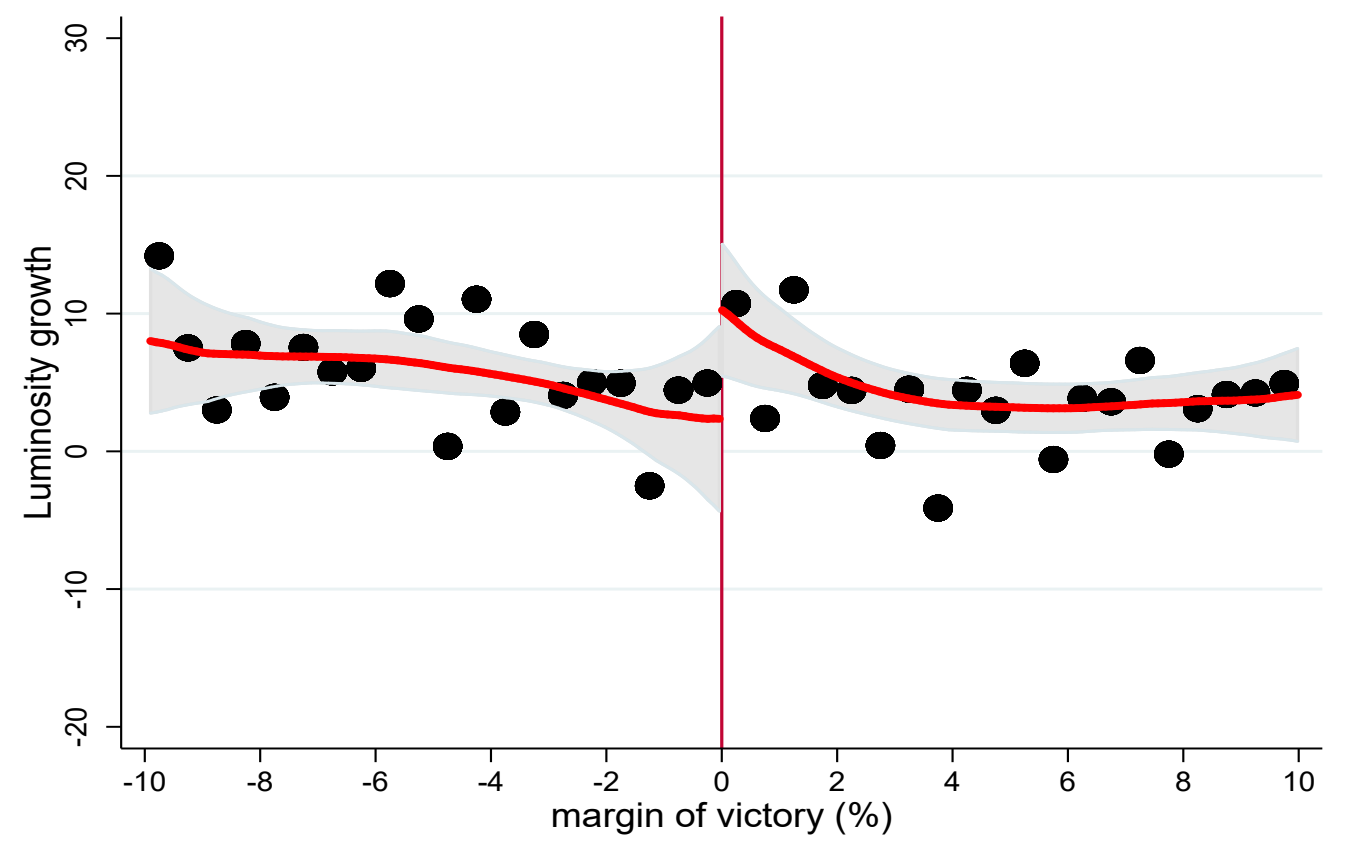

Note: The dependent variable is the growth of light averaged over an election term against the female margin of victory in mixed-gender elections. To account for outliers, we drop observations with an absolute value of light growth over 100 . The victory margin is the difference between the vote shares of the female and male candidates in mixed-gender elections. These are races in which a man and a woman are the top two vote-winners. By construction, the margin of victory is positive when women win and negative when men win. Each dot represents a local average in bins of 0.5 per cent margin of victory. The solid lines are the smooth curves estimated using a local linear regression of each variable on the margin of victory separately on either side of the cutoff of zero, using a triangular kernel and a 5 per cent bandwidth. The figures also depict a 95 per cent confidence interval for each variable around the solid curve.

Source: authors, based on data from the Election Commission of India and NOAA's National Geophysical Data Centre. 
Figure A.2: Differences in legislator characteristics

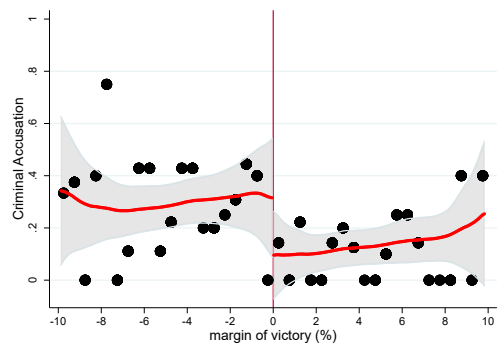

(a) Criminal

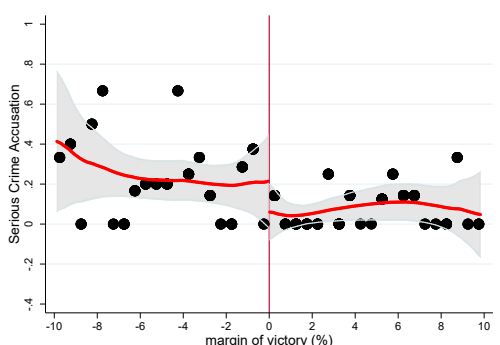

(c) Serious crime dummy

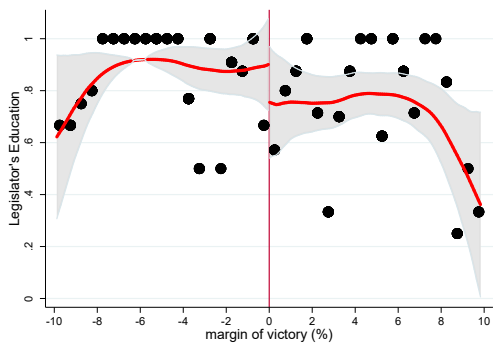

(e) Education

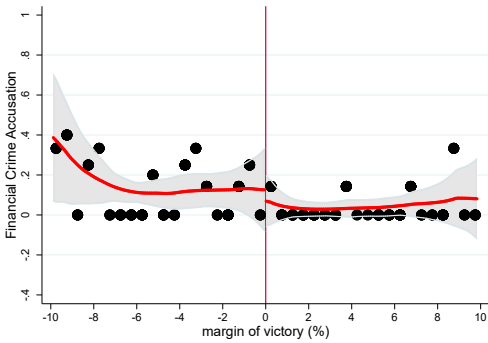

(b) Financial crime dummy

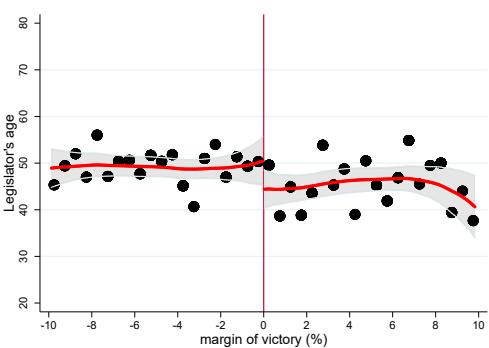

(d) Winner's age

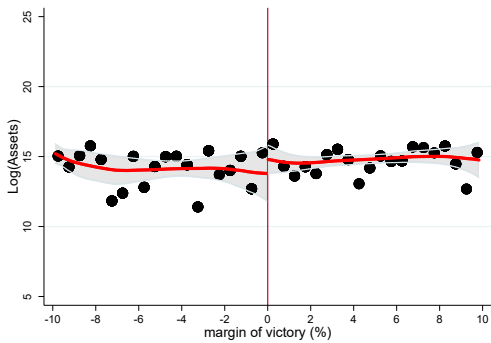

(f) Total Assets

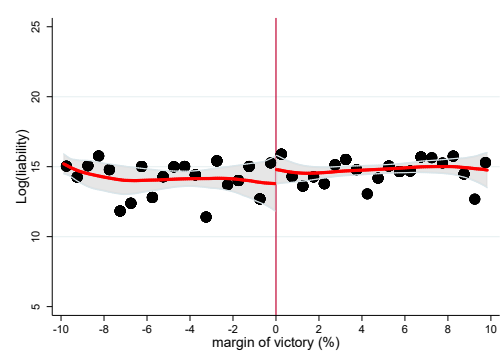

(g) Total Liabilities

Note: Each variable is plotted against the female margin of victory in mixed-gender elections, which is the difference between vote shares of a female candidate and male candidate in mixed-gender elections. Mixed-gender elections are those in which a woman either won or was a runner-up against a man. By construction, the margin of victory is positive for female legislators and negative for male legislators. Each dot represents a local average in bins of 0.5 per cent margin of victory. The solid lines are the smooth curves estimated using a local linear regression of each variable on the margin of victory separately on either side of the cutoff of zero, triangular kernel and a 5 per cent bandwidth. The figures also depict a 95 per cent confidence interval for each variable around the solid curve.

Source: authors, based on data from the Election Commission of India. 
Figure A.3: Cross-country relationship between women in parliament and economic growth
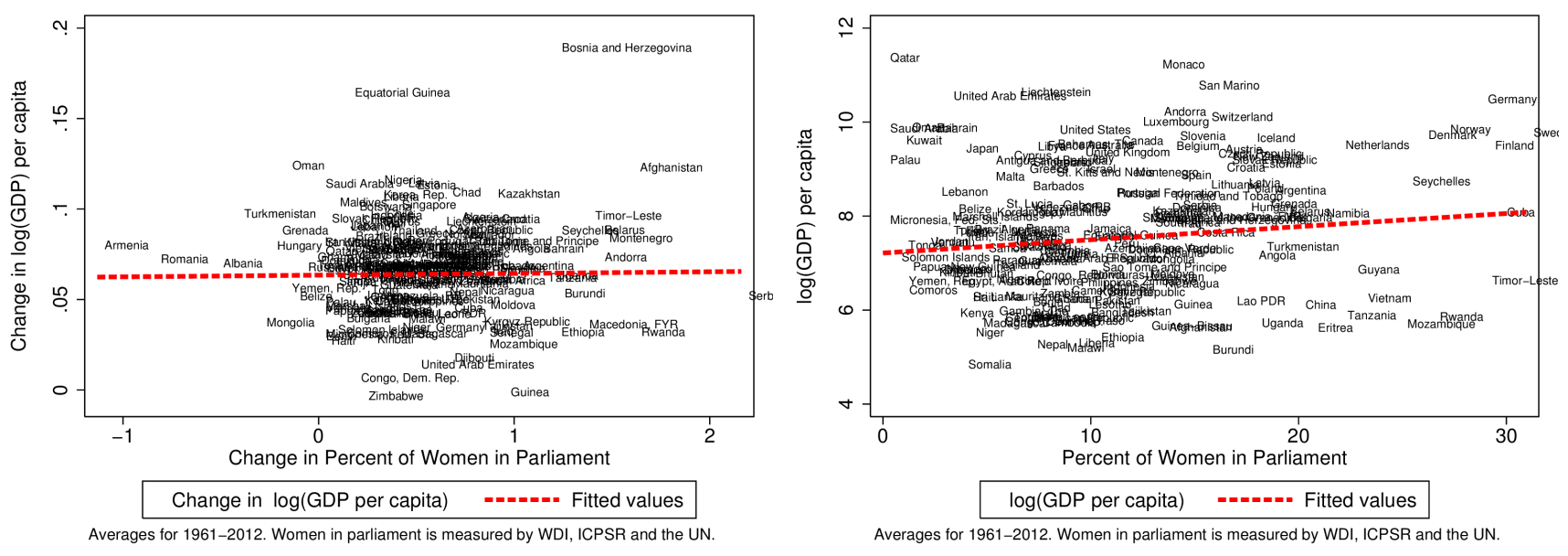

Source: authors, based on data from the WDI, ICPSR, and the UN 